\title{
A Hybrid Framework to Prioritize the Performance Metrics of Reconfigurable Manufacturing System: An Integrated Fuzzy AHP-TOPSIS approach
}

\section{Rajesh Pansare}

Veermata Jijabai Tehnological Institute

GUNJAN YADAV ( $\sim$ gunjanyadav86@gmail.com )

Swarrnim Startup and Innovation University https://orcid.org/0000-0002-2903-3637

\section{Madhukar R Nagare}

Veermata Jijabai Tehnological Institute

\section{Research Article}

Keywords: Reconfigurable Manufacturing System, Multi-criteria Decision Making, Indicators, Performance Metrics, TOPSIS, Fuzzy AHP, Manufacturing System Design

Posted Date: May 27th, 2021

DOl: https://doi.org/10.21203/rs.3.rs-465137/v1

License: (9) This work is licensed under a Creative Commons Attribution 4.0 International License. Read Full License 


\title{
A hybrid framework to prioritize the performance metrics of reconfigurable manufacturing system: An integrated fuzzy AHP-TOPSIS approach
}

\author{
Rajesh Pansare \\ Research Scholar, \\ Production Engineering Department \\ Veermata Jijabai Tehnological Institute \\ Mumbai (India) \\ Email: rajeshpansarevjti@gmail.com
}

* Dr. Gunjan Yadav (Corresponding author)

Associate Professor \& Head

Mechanical Engineering Department

Swarnim Startup \& Innovation University

Gujarat (India)

Email: gunjanyadav86@gmail.com

Mob: +919993996412

ORCID: 0000-0002-2903-3637

\section{Dr. Madhukar R. Nagare}

Associate Professor,

Production Engineering Department

Veermata Jijabai Tehnological Institute

Mumbai (India)

Email: mrnagarevjti@gmail.com 


\title{
A hybrid framework to prioritize the performance metrics of reconfigurable manufacturing system: An integrated fuzzy AHP-TOPSIS approach
}

\begin{abstract}
:
The Reconfigurable Manufacturing System (RMS) meets the challenges of dynamic customer demands, technological advancements, and reducing lead time, among other things. It is necessary to have a framework that can assist in increasing RMS adoption as well as evaluating its performance. The present study seeks to develop a hybrid framework for prioritizing performance metrics of RMS that helps the designers of the manufacturing system in decision making. A total of 31 indicators for RMS are identified through a literature survey, the weight of each indicator is computed by Fuzzy-AHP (Analytic Hierarchy Process) method and the Fuzzy-TOPSIS (Technique for Order Preference by Similarity to Ideal Solution) method is used to prioritize 22 performance metrics of RMS. The findings of the presented study reveal that among all the main indicators; smart factory indicators have the highest weightage followed by strategy and policy indicators. The prioritization of performance metrics shows that lead time, reconfiguration time, and product flexibility are the top three most important performance metrics for RMS. The feasibility and appropriateness of the framework is tested through a case application of the manufacturing organization. The framework developed has a high capacity to assist designers during the adoption of the RMS and will facilitate the identification of the relevant parameters. Authors believe that researchers and professionals will find this study as a ready reference for stepwise adoption of RMS. The study presented here is likely the first to present a hybrid framework in which a set of indicators and performance metrics are presented together.
\end{abstract}

Keywords: Reconfigurable Manufacturing System, Multi-criteria Decision Making, Indicators, Performance Metrics, TOPSIS, Fuzzy AHP, Manufacturing System Design 


\section{Introduction}

\subsection{Study Motivation}

Customer expectations are constantly changing and are becoming dissimilar due to globalization. The product and its features must therefore be personalized. To achieve such customization, there is a need for a flexible and high-quality manufacturing system that meets the future requirements in complex environments (Haddou Benderbal \& Benyoucef, 2019). According to (Yadav et. al., 2018), manufacturing companies face challenges like fulfilling customized product demands, quick supply, and high quality. RMS, which emerged from the configurable computing system used during the design of computing systems around the 1960s, has been introduced to meet such dynamic conditions. It comprises several modules that can be replaced so that reconfiguration is possible (Abdi \& Labib, 2003), provides a rapid and cost-effective response to fulfill changing customer needs (Battaïa et al., 2017). Introduced by Koren in 1999, RMS overcomes the limitations of the traditional manufacturing system, it can change its structure rapidly in response to market needs (Koren Y. et al., 1999) and consists of Reconfigurable machines whose function and capacity can be configured. The comparison of advanced manufacturing systems like RMS is carried out with Dedicated Manufacturing System (DMS) and Flexible Manufacturing System (FMS) as shown in Table 1,

Table 1: Comparison of manufacturing systems (Abdi \& Labib, 2003)

\begin{tabular}{lccc}
\hline & Comparison of various Manufacturing systems & \\
\hline \multicolumn{1}{c}{ Aspects } & $\begin{array}{c}\text { Traditional } \\
\text { Manufacturing } \\
\text { System such as } \\
\text { DMS }\end{array}$ & $\begin{array}{c}\text { Conventional } \\
\text { Manufacturing } \\
\text { System such as } \\
\text { CMS, FMS }\end{array}$ & $\begin{array}{c}\text { Advanced } \\
\text { Manufacturing } \\
\text { System such as } \\
\text { RMS }\end{array}$ \\
\hline $\begin{array}{l}\text { Technology used for particular time } \\
\text { period }\end{array}$ & Fixed & $\begin{array}{c}\text { Needs to be } \\
\text { adaptable to } \\
\text { Market conditions }\end{array}$ & market \\
$\begin{array}{l}\text { Manufacturing Policy } \\
\text { The gap level between Manufacturing } \\
\text { system and demand variation }\end{array}$ & Stable & Predictable & responsive to market \\
\hline
\end{tabular}

RMS, capable of manufacturing different product families in a short time, at a minimum cost, without sacrificing the quality of the product, high responsiveness, and performance efficiency (Koren \& Shpitalni, 2010). However, for the success of the production system, the time required to bring the product onto the market and the ramp-up time required are becoming more and more crucial. RMS meets most of these challenges in the global market, which traditional manufacturing systems cannot meet due to their 
limitations (Abdi \& Labib, 2004). The adaption of new products by reconfiguration is now possible due to RMS as depicted in Figure 1.

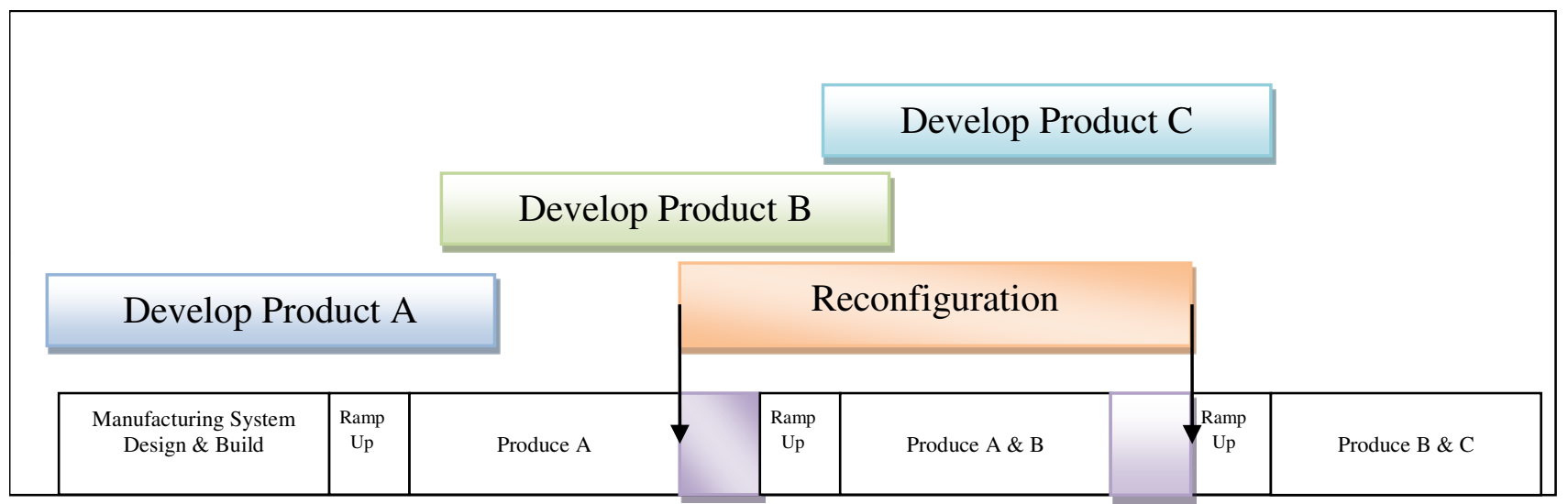

Figure 1: Adaptation to production of new products through rapid reconfiguration (Koren Y. et al., 1999)

\subsection{Need of study}

Available literature describes various frameworks and methodologies that can be used to implement RMS in industrial applications, however, the results of RMS have not yet been proven (Maganha et al., 2018). The core characteristics of RMS are Modularity, Scalability, Convertibility, customization, and Diagnosability which supports the reconfiguration (Singh et al., 2007, Gumasta et al., 2011). Along with this, it is important to identify the factors that help the system to penetrate RMS and are called Indicators. This will help the designer of the manufacturing system to identify and focus on them while implementing the RMS (David et. al., 2001). Also, it is essential to measure the performance of the manufacturing system based on various performance criteria. Qualitative and quantitative criteria should be included for thorough performance analysis of any manufacturing system (Yurdakul, 2002). These factors are termed as performance metrics that enable the evaluation of the RMS, and attempts can be made to improve performance. Also, it is necessary to prioritize them for successful evaluation of system.

\subsection{Research objectives and overall approach}

This paper has the following objectives,

- Identify various indicators of RMS and compute their weights.

- Prioritize and rank the performance metrics of RMS. 
To achieve the aforementioned objectives, a thorough review of RMS articles is conducted, and 31 indicators and 22 performance metrics are identified. The fuzzy AHP method is used to compute indicator weights, followed by the fuzzy TOPSIS method to prioritise performance metrics using expert opinion.

\subsection{Organization of paper}

The paper is organized into a total of 8 sections, including the current section. Section 2 presents the literature review, indicators, and performance metrics of RMS. Section 3 describes the research methodology along with the Fuzzy AHP-TOPSIS method and the various steps followed. Section 4 consists of data collection from experts as well as data analysis whereas section 5 represents the findings of the study. Section 6 constitutes theoretical contributions followed by implications of the study in section 7 . The conclusions, limitations, and future scope are summarized in section 8 .

\section{Literature Review}

The literature review on RMS, indicators, and performance metrics, along with the MCDM approach used, is presented in this section. Below are some of the findings of the literature review,

\subsection{Literature retrieval and selection}

The process of collecting various publications is carried out by retrieving publications from the Scopus database. The search applied consists of keywords such as 'Reconfigurable Manufacturing System', 'Indicators', 'Performance Metrics', 'Assessment of RMS', and 'Enablers'. The publications that appeared in peer-reviewed journals, book chapters, and few renowned conference proceedings are included in the study. Many of these publications are found to be irrelevant to our subject and are then excluded. The exclusion is done by reading the abstract and conclusion of each paper served primarily as an initial screening of research papers. The second stage exclusion was done by reading a full-length paper. All relevant papers so collected are then stored in one place so that they can be retrieved as and when required. The word relevant refers to the publications that present various frameworks, indicators, barriers, and assessments of RMS. Finally, 281 papers are selected for the study.

These 281 papers are further divided into three categories; the first category consists of all papers related to frameworks, RMS optimization techniques. The second category consists of papers in which various indicators, RMS assessment, performance metrics are discussed. The third category consists of 
papers using various MCDM techniques. Research papers of the first two categories are thoroughly studied to identify indicators and performance metrics for RMS. Certain indicators and performance metrics found to be general, applicable to any manufacturing system, are also considered for study purposes. Initially, all of these indicators and performance metrics are listed in the Microsoft Excel file, regardless of their meaning and repetitive nature. It is noted that most researchers considered the key characteristics of RMS to develop methodologies and frameworks to optimize performance (Chaube et al., 2012; El Maraghy, 2006; Koren et al., 2017). These factors are further sorted and the repetitions are removed. The reframing of these factors is done in such a way as to give them the correct meaning and the list is modified accordingly. References for all of these factors are also added to this table so that the source of the information can be highlighted. The table was finally prepared with 31 indicators as shown in Table 2 and 22 Performance Metrics as shown in Table 3.

\subsection{Reconfigurable Manufacturing System (RMS)}

RMS is one of the most recent manufacturing systems that can provide flexibility at the lowest possible cost. The design, implementation, reconfiguration control, layout optimization, process planning, and production planning of RMS are key aspects and active research topics (Bi et al., 2008, Bortolini et al., 2018). Reconfigurability is defined as the ability of the manufacturing system to change its production capacity and functionality in a cost-effective way to meet the requirements of a dynamic market (Bi et al., 2008). Also, (El Maraghy, 2006; Mehrabi et al., 2000; Wiendahl et al., 2007) defined RMS as a machine system which with the help of basic process modules that includes hardware and software can be rearranged or replaced in short time duration and reliably. The key enabler of RMS is Reconfigurable Machine Tool (RMT) which is designed specially to customize the product (Chaube et al., 2012). Eguia, et al. (2017), proposed an approach for machine cell design including grouping of machines and cell loading for multiple reconfigurable machine cells having RMT and Computer Numeric Control (CNC). However, the design and implementation of RMS is a major challenge compared to the traditional manufacturing system. Despite the many contributions made by many scientists, the systematic design method of RMS is lacking (Andersen, Brunoe, Nielsen, \& Rösiö, 2017). There is limited evidence of a breakthrough in reconfigurability in the manufacturing sector, and therefore further research and contributions from scientists and professionals in this field are needed. Given this need, the authors identified RMS indicators and performance metrics as discussed below. 


\subsection{Indicators of RMS}

Indicators are the factors that help in RMS penetration in the manufacturing industry. In the $21^{\text {st }}$ century, the manufacturing industries are facing unpredictable and high-frequency changes in market demands. Therefore, there is a need for a manufacturing system having high responsiveness at the minimum setup cost and time. According to (Koren Y. et al., 1999), RMS can meet these requirements of the manufacturing system cost-effectively and quickly. Abdi \& Labib (2004) has developed a reconfiguration link between market requirements and RMS design and have also developed a design loop for manufacturing system design. He also added some additional criteria that are important for the successful implementation of RMS, such as reusability, various costs, operator skills, motivations, employee training, feasibility, process work, etc. Many researchers have tried to identify the key characteristics of RMS so that designers can focus on these factors for successful implementation ( Abdi et al., 2018). Few researchers considered a case study of RMS to identify the prerequisites and barriers to the system and concluded that the development of RMS in the industry is still a challenge and needs to be addressed in future research work. El Maraghy (2006) compared the characteristics of both FMS and RMS. He focused on flexibility and classified it into ten types, such as Machine flexibility, Material handling flexibility, etc., and added that changeability (Changeover ability, Reconfigurability, Flexibility, Transformability, and Agility) is very important for successful RMS implementation. Further, he indexed various enablers of transformability such as Compatibility, Modularity, Scalability, Mobility, and Universality which also helps for RMS implementation. Deif \& ElMaraghy (2006) said that mass customization and responsiveness are two main characteristics of today's manufacturing system. He presented architecture to design RMS starting with market demand to a selection of best configuration. Wiendahl \& Heger, (2011) described a method that would make it possible to calculate the cost of change in any manufacturing company. Whereas Singh et al. (2007) established a decision-making module to evaluate RMS using tangible and intangible factors. He considered criteria and sub-criteria such as measurement, diagnostics, compensation, etc. had an impact on the judgment. Bi et al. (2008) discussed the requirements of the manufacturing system to meet the customer requirements, including shorter lead time, more variant, low and fluctuating volume, low price, etc. However, Mubarok \& Faculty (2010) discussed the SWOT analysis for RMS, considering indicators such as flexibility, quick decision, etc. Gumasta et al. (2011) further categorized core characteristics of RMS, such as detectability, distinguishability, predictability, etc., and tried to measure reconfigurability of RMS. Bortolini et al. (2018) reviewed literature for RMS and included many new factors such as sustainability, Availability, system complexity etc. which contribute to the successful RMS implementation. Prasad \& 
Jayswal (2019) reviewed the flexibility and reconfigurability of the RMS and discussed various types of flexibility such as machine flexibility, operation flexibility etc. Finally, the selected indicators are shown in Table 2.

\section{Table 2: List of Indicators for RMS}

\begin{tabular}{|c|c|c|c|}
\hline $\begin{array}{l}\text { Sr. } \\
\text { No. }\end{array}$ & Name of Indicator & Description & Reference \\
\hline 1 & Agility/ Granularity & $\begin{array}{l}\text { The system can make changes quickly to respond to changing } \\
\text { markets in a short duration of time. }\end{array}$ & $\begin{array}{l}\text { (Sânchez \& Pérez, 2001; } \\
\text { Wiendahl et al., 2007) }\end{array}$ \\
\hline 2 & Reconfigurability & $\begin{array}{l}\text { The ability of the system to switch to another product family } \\
\text { in minimum time and effort. It may include the use of } \\
\text { artificial intelligence to initiate the reconfiguration process. }\end{array}$ & $\begin{array}{l}\text { (El Maraghy, 2006; Goyal, Jain, } \\
\text { \& Jain, 2013b; Wiendahl et al., } \\
\text { 2007) }\end{array}$ \\
\hline 3 & Evolvability & A manufacturing system can generate adaptive evolution. & (Wiendahl et al., 2007) \\
\hline 4 & Integrability & The system can integrate different components. & $\begin{array}{l}\text { (El Maraghy, 2006; Gumasta et } \\
\text { al., 2011) }\end{array}$ \\
\hline 5 & Scalability & $\begin{array}{l}\text { The system can perform under an increased/decreased } \\
\text { workload. }\end{array}$ & $\begin{array}{l}\text { (El Maraghy, 2006; Gumasta et } \\
\text { al., 2011) }\end{array}$ \\
\hline 6 & $\begin{array}{l}\text { Adaptability to } \\
\text { market change }\end{array}$ & $\begin{array}{l}\text { The system can change products, businesses, or services as per } \\
\text { the need of the market. }\end{array}$ & (Chaube et al., 2012) \\
\hline 7 & $\begin{array}{l}\text { Modularity/ } \\
\text { Adjustability }\end{array}$ & $\begin{array}{l}\text { Modularity is the degree to which the components can be } \\
\text { decoupled and recombined to facilitate economical alterations } \\
\text { in the process. }\end{array}$ & $\begin{array}{l}\text { (El Maraghy, 2006; Gumasta et } \\
\text { al., 2011; Yurdakul, 2002) }\end{array}$ \\
\hline 8 & $\begin{array}{l}\text { Recruitment of } \\
\text { Multi-skill } \\
\text { Employees }\end{array}$ & $\begin{array}{l}\text { Multi-skill employees enable the system to adapt to changes } \\
\text { and maintain performance. }\end{array}$ & $\begin{array}{l}\text { (Abdi \& Labib, 2003; Dixit \& } \\
\text { Gupta, 2013) }\end{array}$ \\
\hline 9 & $\begin{array}{l}\text { Innovations in } \\
\text { product \& Process }\end{array}$ & $\begin{array}{l}\text { The innovative discoveries in products and processes enable } \\
\text { easy implementation of RMS. }\end{array}$ & $\begin{array}{l}\text { (Dixit \& Gupta, 2013; Koren Y. } \\
\text { et al., 1999) }\end{array}$ \\
\hline 10 & $\begin{array}{l}\text { Customization and } \\
\text { Design flexibility }\end{array}$ & $\begin{array}{l}\text { Customization represents the alterations made in the system to } \\
\text { fulfill individual customer requirements which also provide } \\
\text { flexibility in designing a product. }\end{array}$ & $\begin{array}{l}\text { (El Maraghy, 2006; Gumasta et } \\
\text { al., 2011; Wiendahl et al., 2007) }\end{array}$ \\
\hline 11 & Kanban Methods & $\begin{array}{l}\text { Kanban is a method to manage product creation with continual } \\
\text { delivery without overburdening development teams. }\end{array}$ & (Dixit \& Gupta, 2013) \\
\hline 12 & Distinguishability & $\begin{array}{l}\text { The property of the system due to which the functionality loss } \\
\text { can be detected. It also includes proper maintenance } \\
\text { requirements. }\end{array}$ & $\begin{array}{l}\text { (Dixit \& Gupta, 2013; Gumasta } \\
\text { et al., 2011; Sânchez \& Pérez, } \\
\text { 2001) }\end{array}$ \\
\hline 13 & Supplier Integration & $\begin{array}{l}\text { It is the extent to which manufacturing system and suppliers } \\
\text { takes part in inventory control, forecasting, planning, etc. }\end{array}$ & (Dixit \& Gupta, 2013) \\
\hline 14 & $\begin{array}{l}\text { Sustainable system } \\
\text { culture }\end{array}$ & $\begin{array}{l}\text { A sustainable system refers to maintaining the environmental } \\
\text { balance, cultural practices, heritage conservation, etc. }\end{array}$ & (Chaube et al., 2012) \\
\hline 15 & $\begin{array}{l}\text { Government } \\
\text { promotion \& } \\
\text { regulations }\end{array}$ & $\begin{array}{l}\text { The encouraging policies and rules of government may } \\
\text { promote the RMS implementation. }\end{array}$ & (Chaube et al., 2012) \\
\hline 16 & $\begin{array}{l}\text { Advanced } \\
\text { Machinery setups }\end{array}$ & $\begin{array}{l}\text { The availability of programmable/reconfigurable machines in } \\
\text { the manufacturing system helps the adoption of RMS. }\end{array}$ & $\begin{array}{l}\text { (Goyal \& Jain, 2016; Haddou } \\
\text { Benderbal et al., 2018) }\end{array}$ \\
\hline
\end{tabular}


17 Transformability

18 Usage of RFID techniques for Diagnosability

19 Industrial \& Social Integration

20 Appropriate practice of automation ability

21 Awareness of economic benefits

22 Digitization of organizational activities

23 Employee teamwork

24 Education and Training of employees

25 Effective utilization of infrastructure

26 Appropriate evaluation of Demand of Product Family/ Diversity

27 Systematic Inventory Control processes

$28 \mathrm{CAD} / \mathrm{CAM}$ technologies

29 Effective assessment of PLM and Reliability

30 Adoption of cyberphysical system

31 Quality Assurance
The capacity of the system to switch over to a new product. It allows quick changeover between products.

Detectability/Diagnosability using RFID techniques is the quality of the manufacturing system due to which it is being detectable or being countable to quickly and easily identify the quality and reliability-related problems.

Industrial integration is the linking of formerly separate enterprises, firms, or processes to reap economies of scale or finance. Social integration is promoting harmonious interaction with all levels of society.

It represents the ability of a system to automate various processes using advanced technology.

It represents the awareness of economic benefits among the employees and management due to the implementation of RMS.

The system can convert and store the information in digital form.

It builds creativity and learning, conflict management becomes easy and develops complementary strengths.

It enables employees to handle new responsibilities which can improve the performance of RMS.

The available infrastructure like space, equipment, etc. may be utilized effectively in RMS.

It is the ability to predict and evaluate the demand for the product so that the manufacturing system can be selected and implemented successfully.

It is the process of maintaining appropriate stock along with the quality of raw material to meet the customer requirements. It also includes the flexibility of the material handling system. Advanced software packages for design and manufacturing are very helpful in changing environments. In the case of complex part geometry, such technologies are very useful.

PLM provides systematic ways to achieve good quality and reliability using fully integrated methods.

It integrates physical systems, computations, and networking. Its main purpose is to control the physical process through feedback.

It is the process of maintaining the desired quality of product through each stage of the manufacturing process.
(El Maraghy, 2006; Goyal et al.,2013a, 2013b; Gumasta et al., 2011; Wiendahl et al., 2007)

(El Maraghy, 2006; Gumasta et al., 2011)

(Chaube et al., 2012)

(Wiendahl et al., 2007)

(Chaube et al., 2012; Dixit \& Gupta, 2013; Haddou Benderbal \& Benyoucef, 2019)

(El Maraghy, 2006; Gumasta et al., 2011)

(Sânchez \& Pérez, 2001)

(Dixit \& Gupta, 2013; Yurdakul, 2002)

(Dixit \& Gupta, 2013)

(Abdi \& Labib, 2004; Haddou Benderbal et al., 2018; Sânchez \& Pérez, 2001; Yurdakul, 2002)

(Dixit \& Gupta, 2013; Koren Y. et al., 1999; Mapes, 2000)

(Dixit \& Gupta, 2013; Koren Y. et al., 1999)

(Haddou Benderbal et al., 2018)

(Dixit \& Gupta, 2013; Mapes, 2000)

(Koren Y. et al., 1999; Lozano, Villa, \& Eguía, 2017)

\subsection{Performance Metrics of RMS}

Performance metrics are the factors that reflect the current status of the manufacturing situation, are related to some specific goals in manufacturing, and reveal a real insight into the performance measurement (Hwang, 2014). Kumar, (2013) defined performance metrics as a measurable quantity that indicates an 
aspect of the specific performance. The study is carried out to identify the performance metrics of RMS as discussed below.

Garbie (2014) considered manufacturing cost to be one of the criteria for RMS performance analysis and measurement, while (Prasad \& Jayswal, 2019b) considered various costs, including manufacturing costs, the sum of all resources used to manufacture the product to evaluate the performance of sustainable manufacturing system. Manpower requirement is another important criterion for assessing the manufacturing system, hence Garbie (2014) while assessing RMS considered overtime costs, which include the amounts paid to workers for additional duties performed by them other than normal working hours. Also, various costs associated with the manufacturing system are important criteria while evaluating RMS hence (Garbie, 2014) considered additional costs, including repairs and maintenance cost of equipment. He also considered depreciation costs of a fixed asset to be other criteria. Likewise, total wages paid to labor (labor cost) indicates overall design effectiveness and overhead expenses is another important factor (Spicer \& Carlo, 2007). Overhead expenses may include rent paid, taxes, communication expenses, etc. (Chen \& Huang, 2006) while reviewing performance measures of manufacturing system, considered various parameters to evaluate the performance and one of them is process capability or operational capability. Product quality is also to be taken into account when assessing RMS, as a result of which (Garbie, 2014) considered number of defective products produced in particular time period as one of the factor.

Considering the importance of lead time, researchers have tried to reduce it so that the product can be delivered to the customer in minimum time and RMS is one of the ways to reduce the same (Garbie, 2014). Another important factor to evaluate RMS is machine utilization which indicates potential output produced when full capacity is used (Garbie, 2014; Mittal \& Jain, 2014; Yurdakul, 2002). While evaluating the performance of a sustainable manufacturing system, (Bi et al., 2008) considered two important factors product durability and product reliability whereas (Mittal \& Jain, 2014) supported this by considering these two factors while evaluating RMS. Further, (Abdi \& Labib, 2011) emphasized the concept of flexibility and categorized it into various types such as product volume flexibility, product (mix) flexibility, and process flexibility. Flexibility in manufacturing indicates the ability of the manufacturing system to deal with mixed parts, mixed volume, and a mixed process called product (mix) flexibility, volume flexibility, and process flexibility respectively. Further, Garbie (2014) considered system productivity as a criterion to evaluate RMS whereas researchers focused on minimizing work in progress (WIP) which indicates semi-finished products which are entered into the production system but not yet completed. Further, customer complaint as a criterion to evaluate RMS because it indicates the quality of the product as well as the happiness of the 
customer regarding that product (Yurdakul, 2002). Lesser customer complaints indicate more customer happiness. Hence, sales growth is yet another important factor related to the performance of RMS (Abdi \& Labib, 2004; Yurdakul, 2002). However, Yurdakul, (2002) expressed that waste in the manufacturing system results in an increase in the cost of the product and does not add value to the product. Further, various wastes, such as overproduction/ wages paid for overproduction, transportation wastes, materials, scrap, rework, manpower etc. should therefore be minimized and their impact on plant performance should be taken into account (Mapes, 2000). Gumasta et al., (2011) further added the relationship between performance measurement and manufacturing system design wherein he considered the on-time-deliveries as an important criterion for measuring performance of manufacturing system. The term Reconfiguration time defined as the time required to changeover from one product to another should be minimum to reduce the lead time and cost required for the same called as set up cost is of great significance because RMS is designed to act in dynamic situations (Mapes, 2000). Further, (Touzout \& Benyoucef, 2019) also added that the number of accidents that have occurred in that manufacturing system and health issues of employees indicates health \& safety of employees which is one of the RMS performance metrics. The performance measures of RMS are also absenteeism and retention of employees. Many researchers have highlighted the importance of the term "Overall Equipment Effectiveness" (OEE). It indicates the extent to which manufacturing facilities/resources are used in relation to their full potential within a scheduled timeframe. According to (Abdi \& Labib, 2003; Goyal et al., 2013b), terms such as the Responsive Index (RI) also need to be measured. Furthermore, (Touzout \& Benyoucef, 2019) suggested that air, water and land pollution resulting from the production system should also be taken into account while evaluating the production system. Finally, the list of the selected 22 performance metrics are shown in Table 3.

Table 3: List of Performance Metrics for RMS

\begin{tabular}{|c|c|c|c|}
\hline $\begin{array}{l}\text { Sr. } \\
\text { No. }\end{array}$ & $\begin{array}{l}\text { Name of } \\
\text { Performance } \\
\text { Metrics }\end{array}$ & Description & Reference \\
\hline 1. & Productivity & $\begin{array}{l}\text { Production rate is the ratio of the number of products produced } \\
\text { and the time spent while producing them. Productivity can be } \\
\text { considered shift-wise. }\end{array}$ & (Garbie, 2014; Mapes, 2000) \\
\hline 2. & $\begin{array}{l}\text { On-time } \\
\text { deliveries }\end{array}$ & $\begin{array}{l}\text { It represents whether the delivery of the product is as per } \\
\text { promise or delays. }\end{array}$ & Gumasta et al., (2011) \\
\hline 3. & $\begin{array}{l}\text { Environmental } \\
\text { Sustainability }\end{array}$ & $\begin{array}{l}\text { It indicates the rates of pollution creation, depletion of non- } \\
\text { renewable sources, etc. }\end{array}$ & (Touzout \& Benyoucef, 2019) \\
\hline 4. & Sales Growth & $\begin{array}{l}\text { It is a metric to measure the increase of revenue over a fixed } \\
\text { time. }\end{array}$ & $\begin{array}{l}\text { (Abdi \& Labib, 2011; Yurdakul, } \\
\text { 2002) }\end{array}$ \\
\hline
\end{tabular}




\begin{tabular}{|c|c|c|c|}
\hline 5. & $\begin{array}{l}\text { Product } \\
\text { Flexibility }\end{array}$ & $\begin{array}{l}\text { It indicates the ability of the system to change its production } \\
\text { volume, type, and process. }\end{array}$ & (Abdi \& Labib, 2011) \\
\hline 6. & $\begin{array}{l}\text { Customer } \\
\text { complaints }\end{array}$ & $\begin{array}{l}\text { It represents the number of complaints raised by customers } \\
\text { while using the product. It also indicates product durability. }\end{array}$ & $\begin{array}{l}\text { (Mittal \& Jain, 2014; Yurdakul, } \\
\text { 2002) }\end{array}$ \\
\hline 7. & $\begin{array}{l}\text { Responsive } \\
\text { Index (RI) }\end{array}$ & $\begin{array}{l}\text { RI represents the speed and economy at which the machine can } \\
\text { handle changes and functional requirements. }\end{array}$ & $\begin{array}{l}\text { (Abdi \& Labib, 2003; Goyal et al., } \\
\text { 2013a) }\end{array}$ \\
\hline 8. & $\begin{array}{l}\text { Percentage of } \\
\text { defective } \\
\text { products }\end{array}$ & $\begin{array}{l}\text { It indicates Conformance of quality which is the degree to } \\
\text { which the manufactured products meet certain design standards } \\
\text { determined by the producer. }\end{array}$ & (Garbie, 2014) \\
\hline 9. & $\begin{array}{l}\text { Total manpower } \\
\text { requirements }\end{array}$ & $\begin{array}{l}\text { The term indicates the total cost of manpower required for } \\
\text { manufacturing. It also indicates total manpower wastage as well } \\
\text { as the cost of overtime given to workers. }\end{array}$ & (Garbie, 2014; Mapes, 2000) \\
\hline 10. & $\begin{array}{l}\text { Manufacturing } \\
\text { Cost }\end{array}$ & $\begin{array}{l}\text { It represents the total cost for material, labor, and overhead } \\
\text { costs in producing the products. }\end{array}$ & (Prasad \& Jayswal, 2019b) \\
\hline 11. & $\begin{array}{l}\text { Equipment } \\
\text { Repairs \& } \\
\text { Maintenance } \\
\text { cost }\end{array}$ & $\begin{array}{l}\text { It represents the total amounts required for repairs and } \\
\text { maintenance of equipment. }\end{array}$ & (Garbie,2014) \\
\hline 12. & $\begin{array}{l}\text { Machine } \\
\text { Utilisation }\end{array}$ & $\begin{array}{l}\text { It represents the measurement of use and performance of } \\
\text { machines used in manufacturing. }\end{array}$ & $\begin{array}{l}\text { (Garbie, 2014; Mittal \& Jain, 2014; } \\
\text { Yurdakul, 2002) }\end{array}$ \\
\hline 13. & Lead Time & $\begin{array}{l}\text { It represents the time required from the start of a process to the } \\
\text { completion of the product. }\end{array}$ & (Garbie,2014) \\
\hline 14. & $\begin{array}{l}\text { Process } \\
\text { capability }\end{array}$ & $\begin{array}{l}\text { It represents the repeatability and consistency of manufacturing } \\
\text { processes when compared with the specification limits of the } \\
\text { product. }\end{array}$ & (Chen \& Huang, 2006) \\
\hline 15. & $\begin{array}{l}\text { Transportation } \\
\text { Wastage }\end{array}$ & $\begin{array}{l}\text { It indicates the unnecessary movement of, double handling of } \\
\text { materials, shuffling of inventory, etc. during manufacturing. }\end{array}$ & (Mapes, 2000) \\
\hline 16. & $\begin{array}{l}\text { Material } \\
\text { Wastage/ Scrap }\end{array}$ & $\begin{array}{l}\text { It represents the rejected material/ rework required during } \\
\text { manufacturing. }\end{array}$ & (Mapes, 2000) \\
\hline 17. & $\begin{array}{l}\text { Overall } \\
\text { Equipment } \\
\text { Effectiveness }\end{array}$ & $\begin{array}{l}\text { It is the standard used for measuring manufacturing productivity } \\
\text { by identifying the percentage of truly manufacturing time. }\end{array}$ & (Heilala \& Voho, 2001) \\
\hline 18. & $\begin{array}{l}\text { Energy } \\
\text { utilisation/ } \\
\text { Electricity/Fuel } \\
\text { consumption }\end{array}$ & $\begin{array}{l}\text { It is the measure of the benefits due to savings during utilization } \\
\text { of electricity. }\end{array}$ & (Choi \& Xirouchakis, 2015) \\
\hline 19. & $\begin{array}{l}\text { Overproduction } \\
\text { Wastage }\end{array}$ & This indicates manufacturing of products before it is ordered. & (Abdi \& Labib, 2017) \\
\hline 20. & $\begin{array}{l}\text { Health \& Safety } \\
\text { of employees }\end{array}$ & $\begin{array}{l}\text { It represents total health-related complaints reported by } \\
\text { employees. }\end{array}$ & (Dixit \& Gupta, 2013) \\
\hline 21. & $\begin{array}{l}\text { Reconfiguration } \\
\text { time/ Set up } \\
\text { Cost }\end{array}$ & $\begin{array}{l}\text { It indicates the time taken for adjusting machine tools, removing } \\
\text { tools, adding new machine tools, and transporting machine } \\
\text { tools. }\end{array}$ & (Mapes, 2000; Mittal \& Jain, 2014) \\
\hline 22. & $\begin{array}{l}\text { Absenteeism \& } \\
\text { Retention of } \\
\text { employees }\end{array}$ & $\begin{array}{l}\text { It indicates the satisfaction of employees in the present working } \\
\text { environment, space, etc. }\end{array}$ & (Dixit \& Gupta, 2013) \\
\hline
\end{tabular}




\subsection{MCDM techniques used in RMS}

Multi-criteria Decision Analysis (MCDA) or Multi-criteria Decision Making (MCDM) is a branch of Operations research that deals with the design of mathematical and computational tools for the subjective evaluation of the decision alternative in presence of multiple, usually conflicting criteria (Karim \& Karmaker, 2016). The MCDM is used for screening, prioritization, ranking, or selection of various independent, incommensurate, or conflicting sets of alternatives. MCDM is further classified into two categories: MADM (multiple attribute decision making) and MODM (multi objective decision making). MADM is generally used for the discrete and limited number of pre-specified alternatives. Furthermore, MODM is concerned with mathematical optimization problems involving more than one objective function and is to be optimized simultaneously. Some of the recent applications are shown in Table 4.

Table 4: Applications of MCDM for various applications

\begin{tabular}{clll}
\hline $\begin{array}{c}\text { Sr. } \\
\text { No. }\end{array}$ & \multicolumn{1}{c}{ Author Details \& Year } & \multicolumn{1}{c}{ Area of application } & \multicolumn{1}{c}{ Adopted Methodology } \\
\hline 1. & (Anand \& Kodali, 2008) & $\begin{array}{l}\text { Selecting Lean Manufacturing System } \\
\text { (LMS) }\end{array}$ & $\begin{array}{l}\text { Preference ranking organization } \\
\text { method for enrichment } \\
\text { evaluations (PROMETHEE) }\end{array}$ \\
2. & (Abdi \& Labib, 2011) & Performance evaluation of RMS & Analytic Network Process (ANP) \\
3. & (Amalnick et al., 2016) & $\begin{array}{l}\text { Cloud manufacturing resource allocation } \\
\text { Operator selection of cellular manufacturing }\end{array}$ & FAHP-FTOPSIS \\
4. & (Azadeh et al., 2011) & FAHP-FTOPSIS & Intuitionistic fuzzy AHP \\
5. & (Büyüközkan \& Göçer, 2017) & $\begin{array}{l}\text { Rank competing supplier alternatives } \\
\text { Ranking of facilitators for Agile }\end{array}$ & MOORA, VIKOR \\
6. & (Sindhwani \& Malhotra, & $\begin{array}{l}\text { Manufacturing System } \\
\text { Evaluation and optimization of the design } \\
\text { schemes of reconfigurable machine tools } \\
\text { based on multiple-attribute decision-making } \\
\text { Justification for the selection of an RMS: a } \\
\text { fuzzy AHP }\end{array}$ & VIKOR \\
& (Yi, Wang, \& Zhao, 2018) & AHP \\
\hline 8. & (Singh et al., 2007) & & \\
\hline
\end{tabular}

\subsection{Gaps identified through literature}

Based on the literature review, the gaps identified are as follows,

- Most of the RMS literature focuses on the identification of key characteristics, however, outright identification of indicators seems to be unexplored.

- Few studies presented the evaluation of RMS using a set of criteria, however, there is a need to explore the complete evaluation of RMS using the full set of performance metrics.

- A limited number of studies have published the framework to improve the performance of RMS by identifying and prioritizing performance metrics of RMS. 
- Very few studies considered expert opinion to improve the performance of RMS; however, the presented study considers expert opinion for better improvements.

- The literature, strategy, and decision-based problems of RMS reveal that statistical analysis and MCDM techniques can assist in problem-solving.

The above discussion indicates the gap in the literature which highlights the need for MCDM techniques for RMS indicators and performance metrics.

\section{Research Methodology}

This section describes the complete methodology adopted to carry out the research. Figure 2 depicts the flow chart of the research methodology adopted.

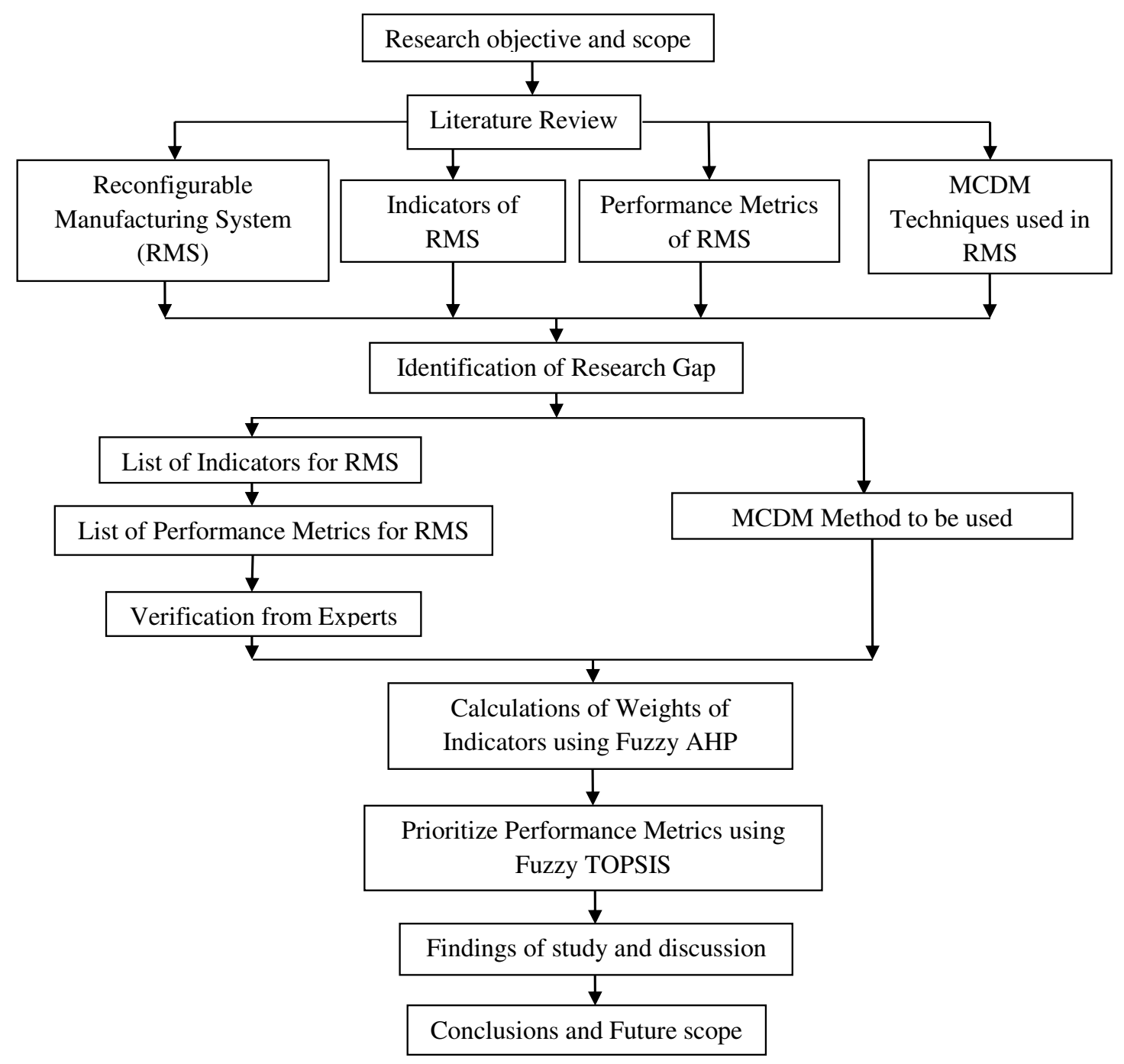

Figure 2: Flow chart for Research methodology 
A literature review is carried out to identify various indicators and performance metrics for RMS. The selected indicators were categorized into five major groups: Strategy and policy indicators, Managerial and HR indicators, Organizational indicators, Tangible and intangible indicators, Technical and Smart factory indicators. The inputs from various experts are collected for the hybrid fuzzy AHP-TOPSIS approach. This approach is helpful not only to compute the weights of indicators but also to prioritize the performance metrics of RMS. Figure 4 shows a flow chart of the three-stage hybrid approach used to carry out the above process.
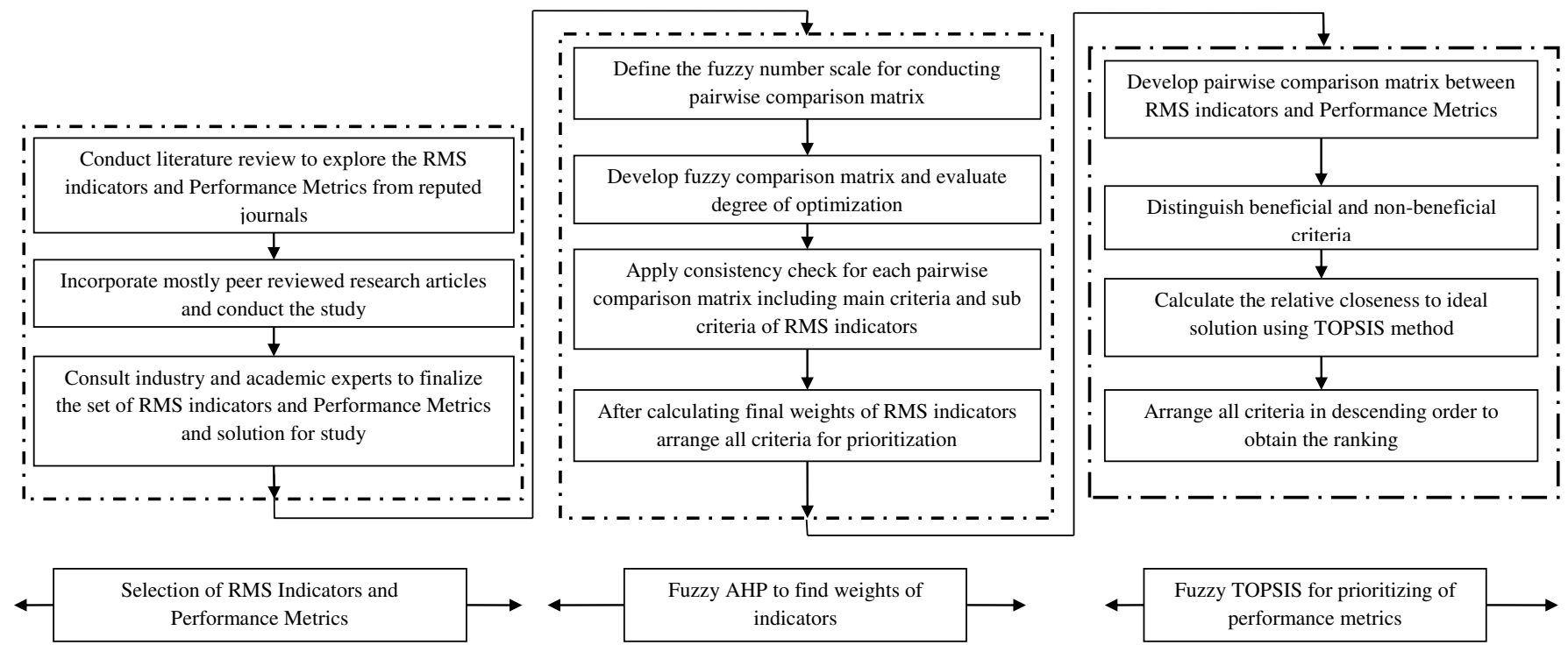

Figure 4: A proposed three-stage hybrid framework

\subsection{Determining criteria weights by FAHP}

AHP is an MCDM tool for complex decision-making processes based on mathematics and psychology, developed by Thomas L. Saaty (Karim \& Karmaker, 2016). While evaluating alternative solutions, we need to attach weights to the criteria to ensure the correct conclusion. AHP is the most accurate method for quantifying the weights of criteria. The degree of relative importance is obtained using a pairwise comparison matrix which is developed using Saaty 1-9 preference scale (Amalnick et al., 2016; Yadav et al., 2018).

In AHP, decision-makers are asked to compare the two individual criteria with finite value, but it is very difficult in practice. In many cases, the decision-maker may be influenced by bias and might contain vagueness during their decision-making. To avoid this, (Chang, 1996) proposed an approach of Fuzzy AHP 
based on the extent analysis method and is widely used for supplier selection problems. In this method, linguistic variables are used to express the comparative judgment of the decision-maker. The integrated Fuzzy-AHP process helps practitioners to achieve the best possible solution by considering different types of fuzzy members. The most commonly practiced fuzzy number is triangular fuzzy member wherein the limit range is obtained by considering alpha cut values which are later converted into the crisp number for analysis purposes. The entire fuzzy AHP process is executed using the following steps (Büyüközkan \& Göçer, 2017),

i. The relationship between the two criteria is allotted through fuzzy numbers mentioned in the scale of relative importance as shown in table 5.

\section{Table 5: Fuzzy numbers and their membership function}

\begin{tabular}{cc}
\hline Fuzzy Number & Membership Function \\
\hline$\tilde{1}$ & $(1,1,3)$ \\
$\tilde{3}$ & $(1,3,5)$ \\
$\tilde{5}$ & $(3,5,7)$ \\
$\tilde{7}$ & $(5,7,9)$ \\
$\tilde{9}$ & $(7,9,11)$ \\
\hline
\end{tabular}

This means that if the fuzzy number 1 is assigned to a relationship between two criteria, it means that, instead of considering a finite value, the whole area covered by the triangle of its corresponding membership function is considered to have a relationship as shown in Figure 3.

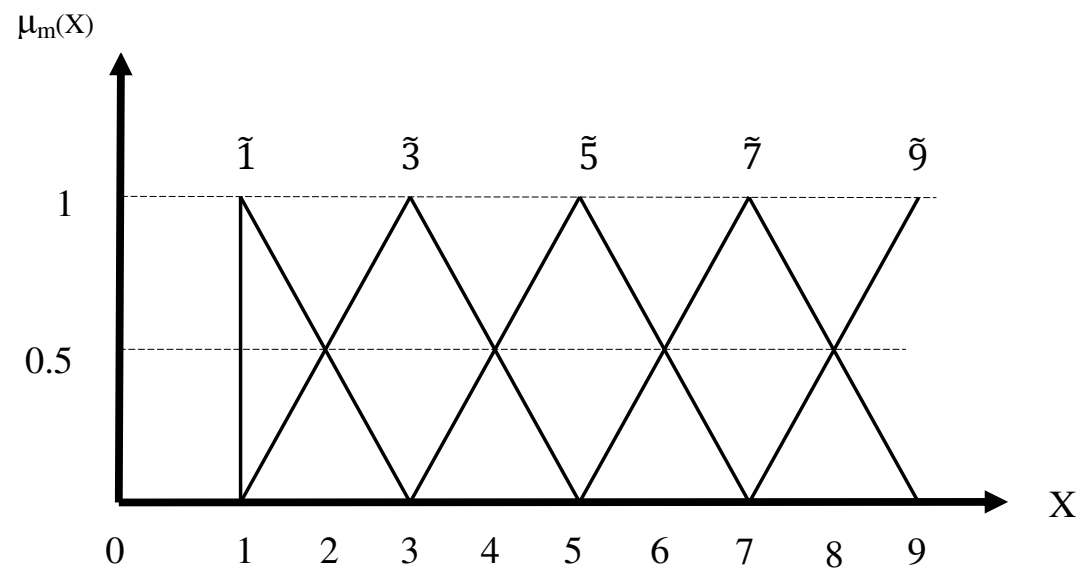

Figure 3: Triangular Fuzzy numbers

ii. After obtaining the membership function, the next step includes defining the range for the comparison between two specific criteria. This range is obtained by following alpha cut values, 


$$
\left[1^{\alpha}, \mu^{\alpha}\right]=[(\mathrm{m}-1) \alpha+1,-(\mathrm{u}-\mathrm{m}) \alpha+\mathrm{u}]
$$

Where $1, \mathrm{u}, \mathrm{m}$ are the lower, middle, and upper value of membership function whereas $\alpha=0.5$

iii. Once the range between comparison allotment is obtained, the next step includes the conversion alpha cut matrix into the corresponding crisp comparison matrix by using the relation as follows,

$$
\tilde{a}_{i j}^{\alpha}=\mu a_{i j l}^{\alpha}+(1-\mu) a_{i j u}^{\alpha}
$$

Where $a_{i j l}^{\alpha}$ is the lower value of the range

$a_{i j u}^{\alpha}$ is upper value of the range

$\mu$ is the degree of optimization taken as 0.5

iv. Once a crisp comparison matrix is obtained the next step includes the checking of matrix consistency by computing the Eigenvector and then the standard procedure of traditional AHP is followed as explained in subsequent steps.

v. The decision-makers are asked to compare the pair of each criterion in a single matrix. Compute the square of the initial matrix to perform the first iteration.

vi. Take the ratio of the sum of the square matrix and then decide the final column by its sum. This will give first Eigenvector.

vii. It is further required to continuously perform the iterations until you obtain the common Eigenvector in two consecutive iterations.

viii. After obtaining the final Eigenvector, indicate that Eigenvector as ' $\mathrm{X}$ ' and identify the value of $\lambda_{\max }$ by using the following relation,

$$
\mathrm{AX}=\lambda_{\max } \mathrm{X}
$$

It is desired to first find the product of $\mathrm{AX}$ and later compare it with $\lambda_{\max } \mathrm{X}$.

ix. After computing $\lambda_{\max }$, the next step is to compute consistency index using the relation,

$$
\text { C.I. }=\frac{\lambda_{\max }-n}{n-1}
$$

Where $\mathrm{n}$ is the number of criteria included in the problem.

x. Finally, it is required to obtain consistency ratio which is obtained by,

$$
C . R .=\frac{C . I .}{R . I .}
$$


Here, R.I. indicates the random index. It is further required to check whether the consistency ratio is less than 0.1. If the value of C.R. exceeds 0.1 then it indicates that the Eigenvectors obtained are not consistent. The value of R.I. can be obtained from table 6 ,

\section{Table 6: Random index numbers}

\begin{tabular}{lllccccr}
\hline No. of Criteria & 1. & 2. & 3. & 4. & 5. & 6. & 7. \\
\hline R.I. & 0 & 0 & 0.52 & 0.89 & 1.11 & 1.25 & 1.35 \\
\hline
\end{tabular}

\subsection{TOPSIS Method}

TOPSIS, developed by Hwang and Yoon in 1981, is a MADM technique based on a comparison of different alternatives with a Negative Ideal Solution (NIS) and a Positive Ideal Solution (PIS). In this method, the ideal solution is the longest distance from the NIS as well as the shortest distance from the PIS (Dağdeviren, 2010). The following steps are to be followed for TOPSIS (Ighravwe \& Oke, 2017; Karim \& Karmaker, 2016),

i. Construct normalized decision matrix which transforms various attribute dimensions into nondimensional attributes. We can use,

$$
\begin{gathered}
r_{i j}=\frac{x_{i j}}{\sqrt{\sum x_{i j}^{2}}} \quad \quad \text { For } \mathrm{i}=1,2,3,---------m \\
j=1,2,3,--------n
\end{gathered}
$$

ii. Construct the weighted normalized matrix. Multiply each column of the normalized decision matrix by its associated weight. An element of new matrix is,

$$
v_{i j}=w_{i j} \cdot r_{i j}
$$

iii. Determine the positive ideal solution and negative ideal solutions using the following relation, The positive ideal solution,

$$
\begin{gathered}
A^{*}=\left\{V_{1}^{*}, V_{2}^{*}-----V_{n}^{*}\right\} \\
V_{j}^{*}=\left\{\left(\max \left(V_{i j}\right) \text { if } j \in J\right),\left(\min \left(V_{i j}\right) \text { if } j \in J^{\prime}\right)\right\}
\end{gathered}
$$

The negative ideal solution,

$$
A^{\prime}=\left\{V_{1}^{\prime}, V_{2}^{\prime}-----V_{n}^{\prime}\right\}
$$




$$
V_{j}^{\prime}=\left\{\left(\max \left(V_{i j}\right) \text { if } j \in J\right),\left(\min \left(V_{i j}\right) \text { if } j \in J^{\prime}\right)\right\}
$$

Where $\mathrm{J}$ is associated with beneficial criteria whereas $\mathrm{J}$ ' is associated with non-beneficial criteria.

iv. Calculate the separation measures for each alternative,

The separation measures for the positive ideal solution (PIS) is,

$$
S_{i}^{*}=\sqrt{\sum_{j}\left(V_{j}^{*}-V_{i j}\right)^{2}}
$$

Where, $\mathrm{i}=1,2,3$----------m

Similarly, the separation measures for the negative ideal solution (NIS) is,

$$
S_{i}^{\prime}=\sqrt{\sum_{j}\left(V_{j}^{\prime}-V_{i j}\right)^{2}}
$$

Where, $\mathrm{i}=1,2,3---------m$

v. Calculate the relative closeness to the ideal solution,

$$
C_{i}^{*}=\frac{S_{i}^{f}}{\left(S_{i}^{*}+S_{i}^{\prime}\right)}
$$

\section{Case application}

The authors agreed to check the appropriateness of their hybrid framework for $\mathrm{ABC}$ manufacturing organization (established in the year 2008) as a case application, as seen in (Yadav et al., 2018). This helps to understand the working of the hybrid framework as well as demonstrates its ability for researchers and practitioners. It reduces the gap between theoretical studies and practical situations. The main intention of this work is to demonstrate the ability of the developed framework to researchers and practitioners. The considered $\mathrm{ABC}$ manufacturing organization is located at Bhiwandi, Thane district. The organization produces a wide range of control valves (such as Globe control valve, Butterfly control valve, Ball valves, Flush Bottom valves, Pressure regulating valve, De-super heater, etc.). The company having a total of around 70 employees operates in general shift and having an approximate turnover of ₹25 crores. The organization supplies its products mainly to Siemens India Limited, Rotork Limited, Space alloys, Siddhi cast, and many more. 


\subsection{Problem description}

$\mathrm{ABC}$ manufacturing organization is facing many challenges due to increasing competition, changing customer demands, etc. Hence there is a need for techno-managerial solutions such as indicators, performance metrics in the manufacturing organization to reduce the lead time, manufacturing cost, and many more advantages. The kind of framework developed in this work requires the commitment of top management for implementation, as the training and resources play a vital role for it. The challenges were increasing in front of $\mathrm{ABC}$ organization as all competing organizations started to implement various technologies in their organization such as $5 \mathrm{~S}$, Kaizen, Industry 4.0, and many more. The management of $\mathrm{ABC}$ organization is matured enough and was keen to implement such kind of framework as their products are changing continuously. The experience and cooperation of staff and officers have been very helpful during the framework development. After a proper understanding of the concept, the top management of $\mathrm{ABC}$ organization realized that they could reduce lead time and manufacturing costs with the help of a developed framework. During the discussion with $\mathrm{ABC}$ management, they also expressed that they could not get some of the orders because they could not supply the product in time which incurred a financial loss to them. Management also realized that the quality of their products can also be improved along with increased profit share due to the implementation of this framework. For this reason, the management of the $\mathrm{ABC}$ organization decided to participate in the framework development without wasting any more time.

The management of $\mathrm{ABC}$ organization expressed their desire to study all Indicators and Performance Metrics, particularly smart factory indicators, during the first meeting. So the authors decided to handover the detailed list of the same to the $\mathrm{ABC}$ management so that they could understand it clearly. This approach of management indicates their interest while developing the hybrid framework and the maturity shown by management was very helpful during the study.

\subsection{Data collection and Framework development}

Stage 1: Shortlisting of indicators and their performance metrics

As discussed earlier, all the indicators and performance metrics identified through the literature review are presented to the expert panel as observed in the study (Yadav et al., 2018). The expert panel studied the list of all indicators and performance metrics and did the necessary shortlisting. The experts suggested categorizing all indicators into various subgroups: Strategy and policy indicators, Managerial and 
HR indicators, Organizational indicators, Tangible and intangible indicators, Technical indicators, and Smart factory indicators as shown in Figure 5.

\section{Stage 2: Identification of indicators weights using Fuzzy AHP}

Indicators identified through the literature review were presented to the panel for their expert opinion as per the study (Yadav et al., 2018). They were requested to provide their expert opinion (comparison matrix) necessary for the preparation of the decision hierarchy so that they could be prioritized. The structure in the form of groups as shown in Figure 5 could be adopted for indicators and the proven method for grouping is to seek help from subject experts.

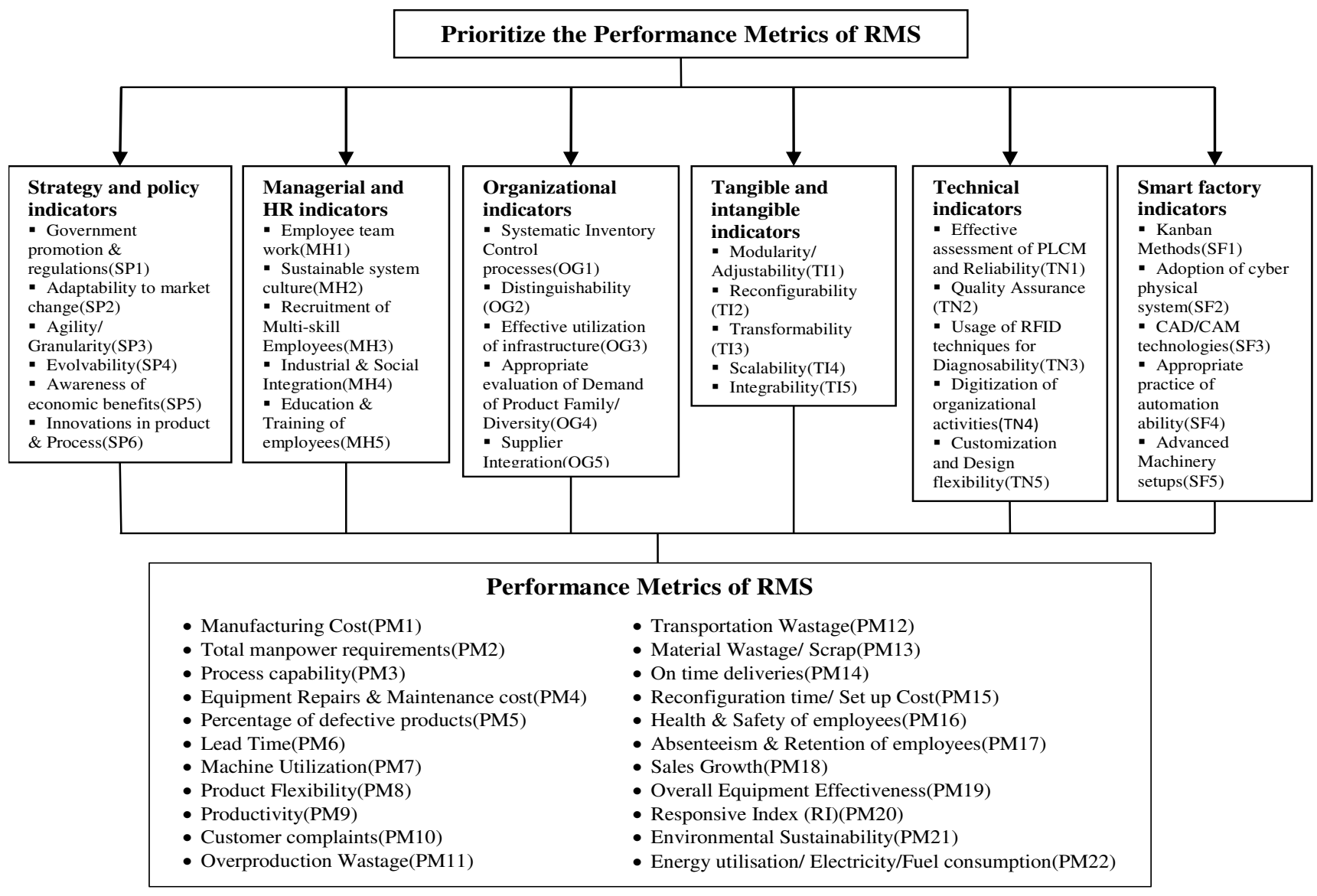

Figure 5: Hierarchical structure of Indicators

The hierarchy of importance of these fuzzy numbers was explained to the experts and asked to prepare an initial pairwise comparison matrix using a five-point scale as shown in Table 7. 
Table 7: Relative importance scale (Yadav et al., 2018)

\begin{tabular}{lcc}
\hline \multicolumn{1}{c}{ Variables } & Fuzzy notification & Corresponding membership function \\
\hline Equal preference & $\widetilde{M 1}$ & $(1,1,3)$ \\
Weak preference & $\widetilde{M 3}$ & $(1,3,5)$ \\
Strong preference & $\widetilde{M 5}$ & $(3,5,7)$ \\
Very strong preference & $\widetilde{M 7}$ & $(5,7,9)$ \\
Extremely strong preference & $\widetilde{M 9}$ & $(7,9,11)$ \\
\hline
\end{tabular}

The panel of eight experts from the $\mathrm{ABC}$ organization prepared a pair-wise comparison as shown in Table 8-14. The standard procedure of Fuzzy-AHP as described earlier is followed to calculate the weights of all indicators. During this process, complete precautions have been taken for consistency and, if any matrix as stated above is found to be inconsistent, experts are requested to revise their opinion for pair-wise comparison.

Table 8: Pairwise comparison matrix for main criteria indicators

\begin{tabular}{|c|c|c|c|c|c|c|}
\hline Main Criteria & $\begin{array}{l}\text { Strategy and } \\
\text { Policy }\end{array}$ & Organisational & $\begin{array}{l}\text { Tangible and } \\
\text { Intangible }\end{array}$ & $\begin{array}{c}\text { Managerial } \\
\text { and HR }\end{array}$ & $\begin{array}{c}\text { Smart } \\
\text { factory }\end{array}$ & Technical \\
\hline Strategy and Policy & $\widetilde{M 1}$ & $\widetilde{M 5}$ & $\widetilde{M 3}$ & $\widetilde{M 1}$ & $\widetilde{M 3}$ & $\left(\overline{(M 3)^{-1}}\right.$ \\
\hline Organisational & ${\left(\overline{M 5}^{-1}\right.}^{-1}$ & $\widetilde{M 1}$ & $\left(\overline{(M 3}^{-1}\right.$ & ${(\overline{M 5})^{-1}}^{-1}$ & $\left(\overline{(M 3)^{-1}}\right.$ & $\left(\overline{(M 3)}^{-1}\right.$ \\
\hline Tangible and Intangible & ${\left(\overline{(M 3)}^{-1}\right.}^{-1}$ & $\widetilde{M 3}$ & $\widetilde{M 1}$ & $\left(\overline{(M 3}^{-1}\right.$ & $\left(\overline{(M 3)}^{-1}\right.$ & $\overline{(M 7)}^{-1}$ \\
\hline Managerial and HR & $\widetilde{M 1}$ & $\widetilde{M 5}$ & $\widetilde{M 3}$ & $\widetilde{M 1}$ & $\widetilde{M 7}$ & $\left(_{(M 5)}^{-1}\right.$ \\
\hline Smart factory & $\left(\overline{(M 3}^{-1}\right.$ & $\widetilde{M 3}$ & $\widetilde{M 3}$ & $\left(\overline{(M 7}^{-1}\right.$ & $\widetilde{M 1}$ & $\left(\overline{(M 3)}^{-1}\right.$ \\
\hline Technical & $\widetilde{M 3}$ & $\widetilde{M 3}$ & $\widetilde{M 7}$ & $\widetilde{M 5}$ & $\widetilde{M 3}$ & $\widetilde{M 1}$ \\
\hline
\end{tabular}

Table 9: Pairwise comparison matrix for Strategy and Policy indicators

\begin{tabular}{|c|c|c|c|c|c|c|}
\hline $\begin{array}{l}\text { Strategy and } \\
\text { Policy }\end{array}$ & SP1 & SP2 & SP3 & SP4 & SP5 & SP6 \\
\hline SP1 & $\widetilde{M 1}$ & $\overline{(\overline{M 3})^{-1}}$ & $\overline{(M 5}^{-1}$ & $\widetilde{M 1}$ & $\widetilde{(M 3}^{-1}$ & $\widetilde{M 9}$ \\
\hline SP2 & $\widetilde{M 3}$ & $\widetilde{M 1}$ & $\widetilde{M 3}$ & $\widetilde{M 5}$ & $\widetilde{M 7}$ & $\widetilde{M 9}$ \\
\hline SP3 & $\widetilde{M 5}$ & $\left(\overline{(M 3}^{-1}\right.$ & $\widetilde{M 1}$ & $\widetilde{M 9}$ & $\widetilde{M 3}$ & $\widetilde{M 9}$ \\
\hline SP4 & $\widetilde{M 1}$ & $\left(\overline{M 5}^{-1}\right.$ & $(\widetilde{M 9})^{-1}$ & $\widetilde{M 1}$ & $\widetilde{(M 3)}^{-1}$ & $\widetilde{M 5}$ \\
\hline SP5 & $\widetilde{M 3}$ & $(M 7)^{-1}$ & $(M 3)^{-1}$ & $\widetilde{M 3}$ & $\widetilde{M 1}$ & $\widetilde{M 3}$ \\
\hline SP6 & $\left(\overline{(M 9}^{-1}\right.$ & $\left(\overline{M 9}^{-1}\right.$ & $\left(\overline{(M 9)^{-1}}\right.$ & $\left(\overline{(M 5}^{-1}\right.$ & $\widetilde{(M 3}^{-1}$ & $\widetilde{M 1}$ \\
\hline
\end{tabular}

Table 10: Pairwise comparison matrix for Managerial and HR indicators

\begin{tabular}{cccccc}
\hline Managerial and HR & MH1 & MH2 & MH3 & MH4 & MH5 \\
\hline MH1 & $\widetilde{M 1}$ & $\widetilde{(M 5})^{-1}$ & $\widetilde{(M 3})^{-1}$ & $\widetilde{(M 3})^{-1}$ & $\widetilde{(M 7)^{-1}}$ \\
MH2 & $\widetilde{M 5}$ & $\widetilde{M 1}$ & $\widetilde{M 5}$ & $\widetilde{M 3}$ & $\widetilde{(M 3}^{-1}$ \\
MH3 & $\widetilde{M 3}$ & $\widetilde{(M 5}^{-1}$ & $\widetilde{M 1}$ & $\widetilde{(M 3})^{-1}$ & $\widetilde{(M 7)}^{-1}$ \\
MH4 & $\widetilde{M 3}$ & $\widetilde{(M 3}^{-1}$ & $\widetilde{M 3}$ & $\widetilde{M 1}$ & $\widetilde{(M 3}^{-1}$ \\
MH5 & $\widetilde{M 7}$ & $\widetilde{M 3}$ & $\widetilde{M 7}$ & $\widetilde{M 3}$ & $\widetilde{M 1}$ \\
\hline
\end{tabular}


Table 11: Pairwise comparison matrix for Organizational indicators

\begin{tabular}{cccccc}
\hline Organisational & OG1 & OG2 & OG3 & OG4 & OG5 \\
\hline OG1 & $\widetilde{M 1}$ & $\widetilde{M 3}$ & $\widetilde{(M 5)}^{-1}$ & $\widetilde{(M 5}^{-1}$ & $\widetilde{(M 3}^{-1}$ \\
OG2 & $\widetilde{(M 3)}$ & $\widetilde{M 1}$ & $\widetilde{(M 5)}$ & $\widetilde{(M 3}^{-1}$ & $\widetilde{(M 5}^{-1}$ \\
OG3 & $\widetilde{M 5}$ & $\widetilde{M 5}$ & $\widetilde{M 1}$ & $\widetilde{M 3}$ \\
OG4 & $\widetilde{M 5}$ & $\widetilde{M 3}$ & $\widetilde{M 3}$ & $\widetilde{M 1}$ & $\widetilde{M 3}$ \\
OG5 & $\widetilde{M 3}$ & $\widetilde{M 5}$ & $\widetilde{(M 3)})^{-1}$ & $\widetilde{(M 3})^{-1}$ & $\widetilde{M 1}$ \\
\hline
\end{tabular}

Table 12: Pairwise comparison matrix for Tangible and Intangible indicators

\begin{tabular}{cccccc}
\hline $\begin{array}{c}\text { Tangible and } \\
\text { Intangible }\end{array}$ & TI1 & TI2 & TI3 & TI4 & TI5 \\
\hline TI1 & $\widetilde{M 1}$ & $\widetilde{M 3}$ & $\widetilde{M 5}$ & $\widetilde{M 3}$ & $\widetilde{M 5}$ \\
TI2 & $\widetilde{(M 3)^{-1}}$ & $\widetilde{M 1}$ & $\widetilde{M 5}$ & $\widetilde{M 3}$ & $\widetilde{M 3}$ \\
TI3 & $\widetilde{(M 5)^{-1}}$ & $\widetilde{(M 5)^{-1}}$ & $\widetilde{M 1}$ & $\widetilde{(M 5}$ & $\widetilde{M 3}$ \\
TI4 & $\widetilde{(M 3)^{-1}}$ & $\widetilde{(M 3)^{-1}}$ & $\widetilde{M 5}$ & $\widetilde{M 5}$ \\
TI5 & $\widetilde{(M 5)}^{-1}$ & $\widetilde{(M 3)^{-1}}$ & $\widetilde{(M 3)}^{-1}$ & $\widetilde{(M 5)^{-1}}$ & $\widetilde{M 1}$ \\
\hline
\end{tabular}

Table 13: Pairwise comparison matrix for Technical indicators

\begin{tabular}{cccccc}
\hline Technical & TN1 & TN2 & TN3 & TN4 & TN5 \\
\hline TN1 & $\widetilde{M 1}$ & $\widetilde{M 3}$ & $\widetilde{M 1}$ & $\widetilde{M 3}$ & $\widetilde{M 5}$ \\
TN2 & $\widetilde{(M 3})^{-1}$ & $\widetilde{M 1}$ & $\widetilde{(M 3)^{-1}}$ & $\widetilde{(M 5)}^{-1}$ & $\widetilde{(M 3)}^{-1}$ \\
TN3 & $\widetilde{M 1}$ & $\widetilde{M 3}$ & $\widetilde{M 1}$ & $\widetilde{(M 3})^{-1}$ & $\widetilde{M 3}$ \\
TN4 & $\widetilde{(M 3}^{-1}$ & $\widetilde{M 5}$ & $\widetilde{M 3}$ & $\widetilde{M 1}$ & $\widetilde{M 7}$ \\
TN5 & $\widetilde{(M 5})^{-1}$ & $\widetilde{M 3}$ & $\widetilde{(M 3})^{-1}$ & $\widetilde{(M 7)}$ & -1 \\
\hline
\end{tabular}

Table 14: Pairwise comparison matrix for Smart factory indicators

\begin{tabular}{|c|c|c|c|c|c|}
\hline Smart factory & SF1 & SF2 & SF3 & SF4 & SF5 \\
\hline SF1 & $\widetilde{M 1}$ & $(\overline{(M 9)})^{-1}$ & $\left(\overline{(M 5)}^{-1}\right.$ & $\left(\overline{(M 3)}^{-1}\right.$ & $\left(\overline{(M 9)}^{-1}\right.$ \\
\hline SF2 & $\widetilde{M 9}$ & $\widetilde{M 1}$ & $\widetilde{M 3}$ & $\widetilde{M 5}$ & $\widetilde{M 3}$ \\
\hline SF3 & $\widetilde{M 5}$ & $\left(\overline{(M 3)}^{-1}\right.$ & $\widetilde{M 1}$ & $\left(\overline{(M 3)}^{-1}\right.$ & $\overline{(M 5)}^{-1}$ \\
\hline SF4 & $\widetilde{M 3}$ & $(M 5)^{-1}$ & $\widetilde{M 3}$ & $\widetilde{M 1}$ & $(M 3)^{-1}$ \\
\hline SF5 & $\widetilde{M 9}$ & $(M 3)^{-1}$ & $\widetilde{M 5}$ & $\widetilde{M 3}$ & $\widetilde{M 1}$ \\
\hline
\end{tabular}

Finally, the weights of major criteria and sub-criteria were computed using the standard fuzzy-AHP procedure and the obtained weights are presented in Table 15. 
Table 15: Final indicator weights

\begin{tabular}{|c|c|c|c|c|}
\hline Major Criteria & $\begin{array}{l}\text { Major criteria } \\
\text { weights }\end{array}$ & Sub criteria weights & Ratio weights & Final weights \\
\hline & \multirow{5}{*}{0.2280} & SF1 & 0.1898 & 0.0423 \\
\hline Smart factory & & SF2 & 0.2294 & 0.0511 \\
\hline \multirow[t]{4}{*}{ indicators } & & SF3 & 0.1910 & 0.0425 \\
\hline & & SF4 & 0.1939 & 0.0432 \\
\hline & & SF5 & 0.1956 & 0.0435 \\
\hline & \multirow{7}{*}{0.2100} & SP1 & 0.1956 & 0.0410 \\
\hline \multirow{6}{*}{$\begin{array}{l}\text { Strategy and policy } \\
\text { indicators }\end{array}$} & & SP2 & 0.1578 & 0.0331 \\
\hline & & SP3 & 0.1472 & 0.0309 \\
\hline & & SP4 & 0.1104 & 0.0231 \\
\hline & & SP5 & 0.1898 & 0.0398 \\
\hline & & SP6 & 0.1990 & 0.0418 \\
\hline & & TN1 & 0.1951 & 0.0401 \\
\hline \multirow{3}{*}{ Technical indicators } & \multirow{4}{*}{0.2054} & $\mathrm{TN} 2$ & 0.1751 & 0.0359 \\
\hline & & TN3 & 0.2066 & 0.0424 \\
\hline & & TN4 & 0.2177 & 0.0447 \\
\hline \multirow{6}{*}{$\begin{array}{l}\text { Managerial and HR } \\
\text { indicators }\end{array}$} & & TN5 & 0.2053 & 0.0421 \\
\hline & \multirow{5}{*}{0.1315} & MH1 & 0.1666 & 0.0219 \\
\hline & & MH2 & 0.2310 & 0.0304 \\
\hline & & MH3 & 0.1824 & 0.0240 \\
\hline & & MH4 & 0.1930 & 0.0254 \\
\hline & & MH5 & 0.2268 & 0.0298 \\
\hline \multirow{5}{*}{$\begin{array}{l}\text { Organizational } \\
\text { indicators }\end{array}$} & \multirow{5}{*}{0.1162} & OG1 & 0.1811 & 0.0210 \\
\hline & & OG2 & 0.1782 & 0.0207 \\
\hline & & OG3 & 0.1999 & 0.0232 \\
\hline & & OG4 & 0.2473 & 0.0287 \\
\hline & & OG5 & 0.1933 & 0.0224 \\
\hline \multirow{5}{*}{$\begin{array}{l}\text { Tangible and } \\
\text { intangible } \\
\text { indicators }\end{array}$} & \multirow{5}{*}{0.1138} & TI1 & 0.2271 & 0.0258 \\
\hline & & TI2 & 0.2133 & 0.0242 \\
\hline & & TI3 & 0.1870 & 0.0212 \\
\hline & & TI4 & 0.2044 & 0.0232 \\
\hline & & TI5 & 0.1680 & 0.0191 \\
\hline
\end{tabular}

Stage 3: Prioritization of performance metrics using Fuzzy-TOPSIS

All these weights calculated in the above steps are used in the TOPSIS method for the ranking of performance metrics. The five-point scale is used to collect expert opinions as shown in Table 16 and to compare all indicators with performance metrics. 
Table 16: Fuzzy score conversion of linguistic scale (Rao \& Patel, 2010; Yadav et al., 2018)

\begin{tabular}{lcc}
\hline \multicolumn{1}{c}{ Linguistic Term } & Fuzzy Number & Crisp Score \\
\hline Criteria 'A' is very low significant to criteria 'B' & F1 & 0.115 \\
Criteria 'A' is low significant to criteria 'B' & F2 & 0.295 \\
Criteria 'A' and criteria 'B' are equally significant & F3 & 0.495 \\
Criteria 'A' is more significant to criteria 'B' & F4 & 0.695 \\
Criteria 'A' is extremely significant to criteria 'B' & F5 & 0.895 \\
\hline
\end{tabular}

The comparison matrix is presented in table 17, where the numbers presented are fuzzy. Then the various steps explained in 3.2 are followed for the comparison matrix presented in Table 17. The weighted normalized matrix is presented in Table 18 which is obtained by taking the product of the normalized matrix using the crisp score and global weights. 


\section{Table 17: Initial Comparison matrix for TOPSIS}

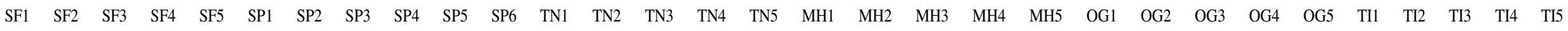

\begin{tabular}{|c|c|c|c|c|c|c|c|c|c|c|c|c|c|c|c|c|c|c|c|c|c|c|c|c|c|c|c|c|c|c|c|}
\hline PM1 & 4 & 4 & 5 & 3 & 5 & 4 & 4 & 3 & 4 & 4 & 4 & 4 & 3 & 4 & 3 & 5 & 4 & 4 & 4 & 2 & 3 & 4 & 3 & 4 & 3 & 3 & 4 & 4 & 4 & 4 & 4 \\
\hline PM2 & 4 & 4 & 3 & 4 & 3 & 3 & 2 & 4 & 3 & 2 & 4 & 3 & 4 & 4 & 2 & 2 & 4 & 4 & 3 & 4 & 4 & 4 & 2 & 3 & 4 & 4 & 3 & 4 & 4 & 2 & 4 \\
\hline PM3 & 4 & 4 & 2 & 5 & 4 & 4 & 3 & 4 & 4 & 2 & 5 & 4 & 3 & 3 & 4 & 4 & 3 & 2 & 4 & 4 & 5 & 4 & 3 & 4 & 3 & 4 & 3 & 3 & 3 & 4 & 3 \\
\hline PM4 & 4 & 3 & 4 & 2 & 4 & 4 & 4 & 3 & 4 & 4 & 2 & 3 & 2 & 4 & 3 & 2 & 2 & 4 & 2 & 4 & 4 & 3 & 3 & 4 & 2 & 4 & 4 & 2 & 3 & 4 & 3 \\
\hline PM5 & 4 & 2 & 4 & 3 & 3 & 4 & 3 & 4 & 3 & 2 & 3 & 4 & 5 & 4 & 4 & 3 & 4 & 5 & 5 & 3 & 5 & 2 & 4 & 3 & 4 & 2 & 2 & 3 & 2 & 4 & 2 \\
\hline PM6 & 4 & 4 & 4 & 5 & 4 & 5 & 4 & 3 & 5 & 3 & 4 & 5 & 4 & 4 & 4 & 4 & 4 & 4 & 5 & 4 & 5 & 4 & 4 & 3 & 4 & 5 & 5 & 4 & 4 & 5 & 4 \\
\hline PM7 & 4 & 3 & 5 & 4 & 5 & 2 & 4 & 3 & 4 & 2 & 3 & 2 & 4 & 4 & 3 & 5 & 4 & 3 & 3 & 4 & 4 & 4 & 4 & 4 & 4 & 4 & 4 & 5 & 5 & 2 & 5 \\
\hline PM8 & 4 & 4 & 5 & 3 & 4 & 3 & 5 & 4 & 5 & 3 & 3 & 5 & 4 & 4 & 3 & 5 & 5 & 3 & 5 & 3 & 5 & 3 & 4 & 4 & 5 & 5 & 4 & 5 & 4 & 5 & 5 \\
\hline PM9 & 3 & 5 & 3 & 5 & 3 & 3 & 3 & 5 & 3 & 3 & 5 & 3 & 4 & 3 & 5 & 4 & 3 & 3 & 4 & 5 & 3 & 5 & 3 & 3 & 3 & 5 & 3 & 3 & 3 & 4 & 3 \\
\hline PM10 & 4 & 3 & 4 & 2 & 4 & 3 & 3 & 4 & 3 & 3 & 4 & 4 & 2 & 3 & 4 & 2 & 3 & 4 & 2 & 5 & 3 & 2 & 4 & 2 & 3 & 2 & 3 & 3 & 2 & 3 & 3 \\
\hline PM11 & 3 & 2 & 4 & 2 & 2 & 4 & 2 & 2 & 4 & 3 & 2 & 4 & 3 & 2 & 2 & 2 & 2 & 3 & 2 & 2 & 4 & 2 & 3 & 2 & 3 & 2 & 3 & 2 & 2 & 2 & 2 \\
\hline PM12 & 3 & 2 & 3 & 2 & 3 & 3 & 2 & 3 & 2 & 4 & 2 & 2 & 2 & 3 & 4 & 2 & 3 & 3 & 3 & 2 & 4 & 2 & 3 & 2 & 4 & 2 & 2 & 3 & 2 & 3 & 2 \\
\hline PM13 & 4 & 3 & 3 & 4 & 4 & 3 & 3 & 2 & 4 & 3 & 2 & 2 & 4 & 3 & 2 & 4 & 3 & 2 & 2 & 2 & 4 & 2 & 2 & 4 & 4 & 2 & 3 & 2 & 4 & 3 & 2 \\
\hline PM14 & 4 & 5 & 4 & 5 & 4 & 5 & 2 & 5 & 4 & 5 & 4 & 3 & 4 & 3 & 4 & 3 & 4 & 3 & 4 & 2 & 4 & 3 & 3 & 4 & 3 & 3 & 3 & 3 & 4 & 4 & 3 \\
\hline PM15 & 5 & 4 & 4 & 3 & 3 & 5 & 3 & 4 & 4 & 5 & 3 & 5 & 4 & 5 & 4 & 3 & 3 & 5 & 3 & 4 & 5 & 4 & 4 & 5 & 4 & 4 & 5 & 4 & 4 & 5 & 4 \\
\hline PM16 & 3 & 3 & 3 & 4 & 3 & 3 & 3 & 3 & 2 & 3 & 3 & 3 & 3 & 2 & 3 & 4 & 2 & 3 & 2 & 2 & 2 & 4 & 2 & 3 & 3 & 3 & 2 & 4 & 2 & 3 & 2 \\
\hline PM17 & 3 & 2 & 4 & 3 & 2 & 3 & 2 & 4 & 3 & 2 & 2 & 3 & 2 & 2 & 2 & 3 & 3 & 2 & 2 & 3 & 2 & 2 & 4 & 2 & 2 & 3 & 2 & 3 & 2 & 2 & 2 \\
\hline PM18 & 3 & 2 & 3 & 2 & 3 & 4 & 2 & 4 & 3 & 2 & 3 & 2 & 3 & 4 & 3 & 2 & 3 & 4 & 2 & 3 & 2 & 4 & 2 & 2 & 3 & 4 & 2 & 2 & 4 & 2 & 3 \\
\hline PM19 & 4 & 3 & 3 & 2 & 3 & 4 & 3 & 2 & 4 & 3 & 3 & 3 & 5 & 2 & 3 & 4 & 3 & 2 & 4 & 3 & 2 & 4 & 3 & 3 & 4 & 4 & 2 & 3 & 3 & 4 & 3 \\
\hline PM20 & 4 & 3 & 4 & 3 & 3 & 3 & 4 & 2 & 2 & 4 & 3 & 2 & 4 & 2 & 2 & 2 & 4 & 3 & 3 & 4 & 3 & 2 & 4 & 3 & 2 & 4 & 2 & 2 & 4 & 2 & 3 \\
\hline PM21 & 4 & 2 & 2 & 3 & 3 & 2 & 2 & 2 & 3 & 3 & 3 & 3 & 2 & 2 & 4 & 2 & 2 & 2 & 2 & 2 & 2 & 2 & 2 & 3 & 2 & 3 & 2 & 3 & 2 & 3 & 3 \\
\hline PM22 & 3 & 4 & 2 & 2 & 2 & 2 & 3 & 3 & 2 & 2 & 4 & 2 & 2 & 2 & 4 & 3 & 3 & 2 & 4 & 3 & 3 & 3 & 4 & 3 & 2 & 2 & 3 & 4 & 2 & 3 & 3 \\
\hline
\end{tabular}


Table 18: Weighted Normalized matrix for TOPSIS

\begin{tabular}{|c|c|c|c|c|c|c|c|c|c|c|c|c|c|c|c|c|c|c|c|c|c|c|c|c|c|c|c|c|c|c|c|}
\hline & $\mathrm{SFI}$ & $\mathrm{SF} 2$ & $\mathrm{SF} 3$ & SF4 & SF5 & SP1 & SP2 & SP3 & SP4 & SP5 & SP6 & $\mathrm{TN} 1$ & $\mathrm{TN} 2$ & TN3 & TN4 & TN5 & MHI & мH2 & Мн3 & MH4 & мH5 & OG1 & OG2 & OG3 & OG4 & OG5 & TII & T12 & $\mathrm{TH}$ & T14 & TI5 \\
\hline PM1 & 0.0097 & 0.0132 & 0.0129 & 0.0077 & 0.0141 & 0.0099 & 0.0094 & 0.0055 & 0.0057 & 0.0110 & 0.0109 & 0.0103 & 0.0064 & 0.0114 & 0.0082 & 0.0140 & 0.0058 & 0.0080 & 0.0062 & 0.0028 & 0.0049 & 0.0056 & 0.0039 & 0.0062 & 0.0054 & 0.0039 & 0.0072 & 0.0063 & 0.0057 & 0.0058 & 0.0052 \\
\hline PM2 & 0.0097 & 0.0132 & 0.0071 & 0.0109 & 0.0078 & 0.0071 & 0.0040 & 0.0078 & 0.0041 & 0.0047 & 0.0109 & 0.0073 & 0.0090 & 0.0114 & 0.0049 & 0.0046 & 0.0058 & 0.0080 & 0.0044 & 0.0066 & 0.0069 & 0.0056 & 0.0024 & 0.0044 & 0.0075 & 0.0055 & 0.0051 & 0.0063 & 0.0057 & 0.0025 & 0.0052 \\
\hline PM3 & 0.0097 & 0.0132 & 0.0043 & 0.0140 & 0.0109 & 0.0099 & 0.0067 & 0.0078 & 0.0057 & 0.0047 & 0.0140 & 0.0103 & 0.0064 & 0.0081 & 0.0115 & 0.0109 & 0.0041 & 0.0034 & 0.0062 & 0.0066 & 0.0089 & 0.0056 & 0.0039 & 0.0062 & 0.0054 & 0.0055 & 0.0051 & 0.0045 & 0.0040 & 0.0058 & 0.0037 \\
\hline PM4 & 0.0097 & 0.0094 & 0.0100 & 0.0046 & 0.0109 & 0.0099 & 0.0094 & 0.0055 & 0.0057 & 0.0110 & 0.0046 & 0.0073 & 0.0038 & 0.0114 & 0.0082 & 0.0046 & 0.0024 & 0.0080 & 0.0026 & 0.0066 & 0.0069 & 0.0040 & 0.0039 & 0.0062 & 0.0032 & 0.0055 & 0.0072 & 0.0027 & 0.0040 & 0.0058 & 0.0037 \\
\hline PM5 & 0.0097 & 0.0056 & 0.0100 & 0.0077 & 0.0078 & 0.0099 & 0.0067 & 0.0078 & 0.0041 & 0.0047 & 0.0077 & 0.0103 & 0.0116 & 0.0114 & 0.0115 & 0.0078 & 0.0058 & 0.0103 & 0.0080 & 0.0047 & 0.0089 & 0.0024 & 0.0055 & 0.0044 & 0.0075 & 0.0023 & 0.0031 & 0.0045 & 0.0024 & 0.0058 & 0.0022 \\
\hline PM6 & 0.0097 & 0.0132 & 0.0100 & 0.0140 & 0.0109 & 0.0128 & 0.0094 & 0.0055 & 0.0073 & 0.0078 & 0.0109 & 0.0133 & 0.0090 & 0.0114 & 0.0115 & 0.0109 & 0.0058 & 0.0080 & 0.0080 & 0.0066 & 0.0089 & 0.0056 & 0.0055 & 0.0044 & 0.0075 & 0.0071 & 0.0093 & 0.0063 & 0.0057 & 0.0075 & 0.0052 \\
\hline $\begin{array}{l}\text { PM7 } \\
\text { lat }\end{array}$ & 0.0097 & 0.0094 & 0.0129 & 0.0109 & 0.0141 & 0.0042 & 0.0094 & 0.0055 & 0.0057 & 0.0047 & 0.0077 & 0.0044 & 0.0090 & 0.0114 & 0.0082 & 0.0140 & 0.0058 & 0.0057 & 0.0044 & 0.0066 & 0.0069 & 0.0056 & 0.0055 & 0.0062 & 0.0075 & 0.0055 & 0.0072 & 0.0081 & 0.0073 & 0.0025 & 0.0067 \\
\hline PM8 & 0.0097 & 0.0132 & 0.0129 & 0.0077 & 0.0109 & 0.0071 & 0.0121 & 0.0078 & 0.0073 & 0.0078 & 0.0077 & 0.0133 & 0.0090 & 0.0114 & 0.0082 & 0.0140 & 0.0074 & 0.0057 & 0.0080 & 0.0047 & 0.0089 & 0.0040 & 0.0055 & 0.0062 & 0.0097 & 0.0071 & 0.0072 & 0.0081 & 0.0057 & 0.0075 & 0.0067 \\
\hline PM9 & 0.0069 & 0.0170 & 0.0071 & 0.0140 & 0.0078 & 0.0071 & 0.0067 & 0.0100 & 0.0041 & 0.0078 & 0.0140 & 0.0073 & 0.0090 & 0.0081 & 0.0148 & 0.0109 & 0.0041 & 0.0057 & 0.0062 & 0.0086 & 0.0049 & 0.0072 & 0.0039 & 0.0044 & 0.0054 & 0.0071 & 0.0051 & 0.0045 & 0.0040 & 0.0058 & 0.0037 \\
\hline PM10 & 0.0097 & 0.0094 & 0.0100 & 0.0046 & 0.0109 & 0.0071 & 0.0067 & 0.0078 & 0.0041 & 0.0078 & 0.0109 & 0.0103 & 0.0038 & 0.0081 & 0.0115 & 0.0046 & 0.0041 & 0.0080 & 0.0026 & 0.0086 & 0.0049 & 0.0024 & 0.0055 & 0.0026 & 0.0054 & 0.0023 & 0.0051 & 0.0045 & 0.0024 & 0.0041 & 0.0037 \\
\hline PMII & 0.0069 & 0.0056 & 0.0100 & 0.0046 & 0.0046 & 0.0099 & 0.0040 & 0.0033 & 0.0057 & 0.0078 & 0.0046 & 0.0103 & 0.0064 & 0.0048 & 0.0049 & 0.0046 & 0.0024 & 0.0057 & 0.0026 & 0.0028 & 0.0069 & 0.0024 & 0.0039 & 0.0026 & 0.0054 & 0.0023 & 0.0051 & 0.0027 & 0.0024 & 0.0025 & 0.0022 \\
\hline PMI2 & 0.0069 & 0.0056 & 0.0071 & 0.0046 & 0.0078 & 0.0071 & 0.0040 & 0.0055 & 0.0024 & 0.0110 & 0.0046 & 0.0044 & 0.0038 & 0.0081 & 0.0115 & 0.0046 & 0.0041 & 0.0057 & 0.0044 & 0.0028 & 0.0069 & 0.0024 & 0.0039 & 0.0026 & 0.0075 & 0.0023 & 0.0031 & 0.0045 & 0.0024 & 0.0041 & 0.0022 \\
\hline PM13 & 0.0097 & 0.0094 & 0.0071 & 0.0109 & 0.0109 & 0.0071 & 0.0067 & 0.0033 & 0.0057 & 0.0078 & 0.0046 & 0.0044 & 0.0090 & 0.0081 & 0.0049 & 0.0109 & 0.0041 & 0.0034 & 0.0026 & 0.0028 & 0.0069 & 0.0024 & 0.0024 & 0.0062 & 0.0075 & 0.0023 & 0.0051 & 0.0027 & 0.0057 & 0.0041 & 0.0022 \\
\hline PM14 & 0.0097 & 0.0170 & 0.0100 & 0.0140 & 0.0109 & 0.0128 & 0.0040 & 0.0100 & 0.0057 & 0.0142 & 0.0109 & 0.0073 & 0.0090 & 0.0081 & 0.0115 & 0.0078 & 0.0058 & 0.0057 & 0.0062 & 0.0028 & 0.0069 & 0.0040 & 0.0039 & 0.0062 & 0.0054 & 0.0039 & 0.0051 & 0.0045 & 0.0057 & 0.0058 & 0.0037 \\
\hline PM15 & 0.0124 & 0.0132 & 0.0100 & 0.0077 & 0.0078 & 0.0128 & 0.0067 & 0.0078 & 0.0057 & 0.0142 & 0.0077 & 0.0133 & 0.0090 & 0.0146 & 0.0115 & 0.0078 & 0.0041 & 0.0103 & 0.0044 & 0.0066 & 0.0089 & 0.0056 & 0.0055 & 0.0080 & 0.0075 & 0.0055 & 0.0093 & 0.0063 & 0.0057 & 0.0075 & 0.0052 \\
\hline PM16 & 0.0069 & 0.0094 & 0.0071 & 0.0109 & 0.0078 & 0.0071 & 0.0067 & 0.0055 & 0.0024 & 0.0078 & 0.0077 & 0.0073 & 0.0064 & 0.0048 & 0.0082 & 0.0109 & 0.0024 & 0.0057 & 0.0026 & 0.0028 & 0.0029 & 0.0056 & 0.0024 & 0.0044 & 0.0054 & 0.0039 & 0.0031 & 0.0063 & 0.0024 & 0.0041 & 0.0022 \\
\hline PM17 & 0.0069 & 0.0056 & 0.0100 & 0.0077 & 0.0046 & 0.0071 & 0.0040 & 0.0078 & 0.0041 & 0.0047 & 0.0046 & 0.0073 & 0.0038 & 0.0048 & 0.0049 & 0.0078 & 0.0041 & 0.0034 & 0.0026 & 0.0047 & 0.0029 & 0.0024 & 0.0055 & 0.0026 & 0.0032 & 0.0039 & 0.0031 & 0.0045 & 0.0024 & 0.0025 & 0.0022 \\
\hline PM18 & 0.0069 & 0.0056 & 0.0071 & 0.0046 & 0.0078 & 0.0099 & 0.0040 & 0.0078 & 0.0041 & 0.0047 & 0.0077 & 0.0044 & 0.0064 & 0.0114 & 0.0082 & 0.0046 & 0.0041 & 0.0080 & 0.0026 & 0.0047 & 0.0029 & 0.0056 & 0.0024 & 0.0026 & 0.0054 & 0.0055 & 0.0031 & 0.0027 & 0.0057 & 0.0025 & 0.0037 \\
\hline PM19 & 0.0097 & 0.0094 & 0.0071 & 0.0046 & 0.0078 & 0.0099 & 0.0067 & 0.0033 & 0.0057 & 0.0078 & 0.0077 & 0.0073 & 0.0116 & 0.0048 & 0.0082 & 0.0109 & 0.0041 & 0.0034 & 0.0062 & 0.0047 & 0.0029 & 0.0056 & 0.0039 & 0.0044 & 0.0075 & 0.0055 & 0.0031 & 0.0045 & 0.0040 & 0.0058 & 0.0037 \\
\hline PM20 & 0.0097 & 0.0094 & 0.0100 & 0.0077 & 0.0078 & 0.0071 & 0.0094 & 0.0033 & 0.0024 & 0.0110 & 0.0077 & 0.0044 & 0.0090 & 0.0048 & 0.0049 & 0.0046 & 0.0058 & 0.0057 & 0.0044 & 0.0066 & 0.0049 & 0.0024 & 0.0055 & 0.0044 & 0.0032 & 0.0055 & 0.0031 & 0.0027 & 0.0057 & 0.0025 & 0.0037 \\
\hline PM21 & 0.0097 & 0.0056 & 0.0043 & 0.0077 & 0.0078 & 0.0042 & 0.0040 & 0.0033 & 0.0041 & 0.0078 & 0.0077 & 0.0073 & 0.0038 & 0.0048 & 0.0115 & 0.0046 & 0.0024 & 0.0034 & 0.0026 & 0.0028 & 0.0029 & 0.0024 & 0.0024 & 0.0044 & 0.0032 & 0.0039 & 0.0031 & 0.0045 & 0.0024 & 0.0041 & 0.0037 \\
\hline PM22 & 0.0069 & 0.0132 & 0.0043 & 0.0077 & 0.0046 & 0.0042 & 0.0067 & 0.0055 & 0.0024 & 0.0047 & 0.0109 & 0.0044 & 0.0038 & 0.0048 & 0.0115 & 0.0078 & 0.0041 & 0.0034 & 0.0062 & 0.0047 & 0.0049 & 0.0040 & 0.0055 & 0.0044 & 0.0032 & 0.0023 & 0.0051 & 0.0063 & 0.0024 & 0.0041 & 0.0037 \\
\hline
\end{tabular}




\subsection{Data analysis}

Various steps for fuzzy-TOPSIS are followed till the distance from the positive ideal solution (PIS), the negative ideal solution (NIS), and the relative closeness from the ideal solution and ranking is obtained. As the values of the relative closeness represent the distance from the negative/worst solution, the highest value is given the top ranking as shown in Table 19.

\section{Table 19: Ranking obtained using TOPSIS}

\begin{tabular}{ccccc}
\hline $\begin{array}{c}\text { Performance } \\
\text { Metrics code }\end{array}$ & $\begin{array}{c}\text { Positive Ideal Solution } \\
\text { (PIS) }\end{array}$ & $\begin{array}{c}\text { Negative Ideal } \\
\text { Solution (NIS) }\end{array}$ & Relative closeness & Ranking \\
\hline PM1 & 0.0179 & 0.0269 & 0.5998 & 4 \\
PM2 & 0.0259 & 0.0204 & 0.4409 & 10 \\
PM3 & 0.0221 & 0.0249 & 0.5291 & 7 \\
PM4 & 0.0270 & 0.0197 & 0.4215 & 9 \\
PM5 & 0.0256 & 0.0223 & 0.4655 & 1 \\
PM6 & 0.0140 & 0.0302 & 0.6835 & 8 \\
PM7 & 0.0231 & 0.0255 & 0.5246 & 3 \\
PM8 & 0.0175 & 0.0295 & 0.6274 & 6 \\
PM9 & 0.0212 & 0.0268 & 0.5589 & 20 \\
PM10 & 0.0272 & 0.0190 & 0.4110 & 19 \\
PM11 & 0.0352 & 0.0127 & 0.2651 & 14 \\
PM12 & 0.0334 & 0.0134 & 0.2867 & 2 \\
PM13 & 0.0294 & 0.0170 & 0.3670 & 16 \\
PM14 & 0.0198 & 0.0276 & 0.5816 & 22 \\
PM15 & 0.0167 & 0.0298 & 0.6403 & 18 \\
PM16 & 0.0294 & 0.0148 & 0.3355 & 13 \\
PM17 & 0.0358 & 0.0107 & 0.2304 & 15 \\
PM18 & 0.0325 & 0.0145 & 0.3084 & 21 \\
PM19 & 0.0281 & 0.0177 & 0.3871 & 17 \\
PM20 & 0.0304 & 0.0162 & 0.3483 & \\
PM21 & 0.0350 & 0.0108 & 0.2360 & 0.3234 \\
PM22 & 0.0320 & 0.0153 & & \\
\hline
\end{tabular}

\section{Findings of the study}

Implementation of the RMS is more costly compared to other manufacturing systems, but the benefits accrue are more than other systems. It is therefore important to ensure the correct implementation of the various indicators and performance metrics, otherwise, the performance and efficiency of the system may be affected. The main objective of this study is to develop a hybrid Fuzzy AHP -TOPSIS framework that can be very useful for decision-making during the implementation of the system. The two phases of this study include the computation of the major criterion and the weights of the sub-criterion indicators. Initially, all 
the major criterion, as well as the sub-criterion, are ranked within the group by computing their relative weights. This helps to compare indicators both within the group and outside the group with the help of global weight. The second phase is to rank shortlisted performance metrics using the Fuzzy-TOPSIS method.

Finally, the results obtained using Fuzzy-AHP and the ranking obtained using Fuzzy-TOPSIS are analyzed for interpretation, revealing that the 'smart factory' indicators have the highest weight among the other indicators followed by the 'strategy and policy' indicators. It demonstrates that the use of advanced manufacturing and material handling technologies can lead to the successful implementation of RMS, and these indicators can improve many important performance metrics, such as lead time, reconfiguration time, etc. Strategy and policy indicators are also very important, as rigid management policies can act as major obstacles to the effective implementation of the RMS. The utilization of technical resources such as digitization and RFID is the key to success in the successful RMS implementation. It is also observed that the education and training of employees has an impact on implementation, as the skills of employees have a major impact on the system. Among the performance metrics, 'Lead time' holds the highest positions which are followed by 'Reconfiguration time' and 'Product flexibility' offered by the manufacturing system. 'Manufacturing cost' is at fourth position, as it is a very important metrics as far as product cost is concerned. 'On-time deliveries' is vital if any manufacturing organization wants to sustain itself in the market, hence it is in the fifth position. The later positions of performance metrics are occupied by 'Productivity', 'Process capability', 'Machine utilization', and 'Percentage of defective Products' etc.

\section{Theoretical contributions of the study}

Many researchers discussed the core characteristics of RMS. At the same time, none of the researchers discussed indicators, their weights, and the ranking of performance metrics for RMS. Hence, this study tries to find indicators and performance metrics of RMS along with their ranking using the hybrid Fuzzy AHP-TOPSIS. This hybrid framework is used to compute the weights of the indicators to assess their influence during the implementation of RMS and these weights are used to rank the performance metrics in link with indicators. Authors expect the presented work will save efforts, time, and funds of practitioners of the manufacturing system. This research can be viewed as a significant contribution to MCDM as well as RMS promoting applications in the domain areas.

The main contribution of this study is the identification of RMS indicators and performance metrics. The exhaustive literature survey is conducted, with 31 indicators and 22 performance metrics that are best 
suited to the RMS manufacturing environment being finalized. Authors have tried to include highly influential domain-specific indicators and performance metrics for RMS and are prioritized for smooth and successful implementation of RMS.

\section{Implications for practitioners and researchers}

The main aim of this paper is to develop a hybrid framework for prioritizing RMS performance metrics. To achieve success in the field of techno-managerial solutions, the key requirement is the hybrid framework (Prashar, 2016; Yadav et al., 2018). The inputs are taken from researchers and industry practitioners. The researchers mainly contribute to the creation of a hybrid framework and mathematical calculations, while the practitioner helps with the inputs of the framework (Yadav et al., 2018). The contribution of both researchers and practitioners is therefore essential for the development of such a framework.

Following implications are important for practitioners and researchers interested in application areas of RMS.

- The study illustrates the use of the Fuzzy AHP-TOPSIS hybrid approach to the RMS framework and provides three main inputs. First, many articles in the field of MCDM (Kurttila et al., 2000; Saaty, 2008) used AHP alone as a methodology in which the chances of vagueness and bias cannot be neglected. This is why Fuzzy-AHP is introduced, which gives the decision-maker flexibility for comparison (Yadav et al., 2018). Second, TOPSIS is used to rank alternatives aimed at finding the best alternative that has the shortest distance from the PIS and at the same time the distance from the NIS (Karim \& Karmaker, 2016). Using AHP's fuzzy theory to assess the weight of TOPSIS parameters will reduce the ambiguity and uncertainties inherent in making decisions on the most efficient number of operators and the successful calculation of RMS operator assignments. Thirdly, the framework developed in this work can be used in any other field, irrespective of the nature of the problem.

- Many studies (Karim \& Karmaker, 2016; Yadav et al., 2018) have tried to focus on the importance of developing a hybrid framework, but there is still a lack of such studies in practice. There is also a need to develop a generalized type of framework that can be used in any application domain with slight modification. This is particularly important in developing countries where the risk of failure to implement cannot be afforded. Such frameworks will therefore be very useful in decision-making areas where indicators and performance metrics play an important role in the manufacturing system. 
- The authors of this work agree that not all indicators can be considered and included during the implementation of the RMS, but based on the weights obtained, important indicators with high-intensity weights can be considered and included. The hybrid framework developed here plays an important role and the author wants to encourage this kind of work in other areas.

- The hybrid framework that has been developed in this way offers many benefits to practitioners and researchers that can show new directions in research. There is still a need to explore more opportunities in this area. The hybrid framework can also be used to assess several other issues in the industry. This developed framework can be taken as a foundational step in this direction.

\section{Conclusions, Limitations, and Future Scope}

The work presented is an initial attempt to improve the adaptability of RMS so that different manufacturing firms wishing to produce different products using the same manufacturing facilities can easily implement RMS. Finalized Indicators and Performance Metrics are evaluated by developing the RMS decision hybrid framework using the Fuzzy AHP-TOPSIS approach. Fuzzy-AHP is used to calculate the Indicators' weights, while Fuzzy-TOPSIS is used to evaluate the Performance Metrics ranking. This will help the practicing managers to take appropriate and timely decisions in the event of RMS adoption and performance measurement. An initial facilitator study can help policymakers understand the potential of actual RMS implementation in the manufacturing industry. The developed hybrid framework is an important techno-managerial solution in the field of RMS. Such work, which can handle both indicators and performance metrics, is rarely reported in the RMS field. The results of this study suggest that 'Smart Factory' indicators have the highest priority, which means that the adoption of the latest and automated manufacturing technologies can improve the performance of RMS. Authors assume that ranking performance metrics will be simpler and more efficient through their analysis and will support the execution of RMS. Manufacturing enterprise management should make a strategic effort to manage RMS applications.

In addition to the above-noted benefits of the study, some of the limitations of the study cannot be neglected. The first major limitation of the study is that if someone is not familiar with MCDM techniques, this framework may increase the complexity of the study. The study presented here is validated by the use of expert data in the form of a matrix of comparison. This work can be extended and simulation-based evaluations can be carried out to compare the results. The experts involved may likely have missed some 
important indicators and performance metrics. Authors appeal to researchers and practitioners to use a specific range of indicators and performance metrics to explore this approach. Researchers may also try to apply this framework to other areas of production and the results can be verified. Authors expect both researchers and practitioners to benefit from experimenting with this study in a variety of sectors and to continue this research work.

\section{DECLARATIONS}

Funding: The authors did not receive support from any organization for the submitted work.

Conflict of Interest: The authors have no conflicts of interest to declare that are relevant to the content of this article.

Availability of data and material: Not Applicable

Code availability: Not Applicable

Ethics approval: The manuscript in part or in full has not been submitted or published anywhere. The manuscript will not be submitted elsewhere until the editorial process is completed.

Consent to participate: Not Applicable

Consent for publication: The author transfers to Springer the non-exclusive publication rights.

Authors' contributions: All authors contributed in writing the manuscript. Mr. Rajesh Pansare has collected the data and performed the analysis. 


\section{References}

Abdi, M. R., \& Labib, A. W. (2004). Grouping and selecting products: The design key of Reconfigurable Manufacturing Systems (RMSs). International Journal of Production Research, 42(3), 521-546. https://doi.org/10.1080/00207540310001613665

Abdi, M. Reza, \& Labib, A. (2017). RMS capacity utilisation: product family and supply chain. International Journal of Production Research, 55(7), 1930-1956. https://doi.org/10.1080/00207543.2016.1229066

Abdi, M. Reza, Labib, A., Edalat, F. D., \& Abdi, A. (2018). RMS Performance Evaluation Using ANP and Holonic Structure. Integrated Reconfigurable Manufacturing Systems and Smart Value Chain, 197215. https://doi.org/10.1007/978-3-319-76846-5

Abdi, M. Reza, \& Labib, A. W. (2011). Performance evaluation of reconfigurable manufacturing systems via holonic architecture and the analytic network process. International Journal of Production Research, 49(5), 1319-1335. https://doi.org/10.1080/00207543.2010.520989

Abdi, M R, \& Labib, A. W. (2004). Feasibility study of the tactical design justification for reconfigurable manufacturing systems using the fuzzy analytical hierarchical process. International Journal of Production Research, 42(15), 3055-3076. https://doi.org/10.1080/00207540410001696041

Abdi, Mohammad Reza, \& Labib, A. W. (2003). A design strategy for reconfigurable manufacturing systems (RMSs) using analytical hierarchical process (AHP): A case study. International Journal of Production Research, 41(10), 2273-2299. https://doi.org/10.1080/0020754031000077266

Amalnick, M. S., Hakimiasl, A., Zanjirani, Y. A., \& Hakimiasl, M. (2016). A Cloud Manufacturing Resource Allocation by Using an Integrated FAHP-FTOPSIS Approach in High-Tech Industries. Applied Mathematics in Engineering, Management and Technology, 4(1), 1-8.

Anand, G., \& Kodali, R. (2008). Selection of lean manufacturing systems using the PROMETHEE. Journal of Modelling in Management, 3(1), 40-70. https://doi.org/10.1108/17465660810860372

Andersen, A. L., Brunoe, T. D., Nielsen, K., \& Rösiö, C. (2017). Towards a generic design method for reconfigurable manufacturing systems: Analysis and synthesis of current design methods and evaluation of supportive tools. Journal of Manufacturing Systems, 42, 179-195. https://doi.org/10.1016/j.jmsy.2016.11.006

Azadeh, A., Nazari-Shirkouhi, S., Hatami-Shirkouhi, L., \& Ansarinejad, A. (2011). A unique fuzzy multicriteria decision making: Computer simulation approach for productive operators' assignment in cellular manufacturing systems with uncertainty and vagueness. International Journal of Advanced Manufacturing Technology, 56(1-4), 329-343. https://doi.org/10.1007/s00170-011-3186-9

Battaïa, O., Dolgui, A., \& Guschinsky, N. (2017). Decision support for design of reconfigurable rotary machining systems for family part production. International Journal of Production Research, 55(5), 1368-1385. https://doi.org/10.1080/00207543.2016.1213451

Bi, Z. M., Lang, S. Y. T., Shen, W., \& Wang, L. (2008). Reconfigurable manufacturing systems: The state of the art. International Journal of Production Research, 46(4), 967-992. https://doi.org/10.1080/00207540600905646

Bortolini, M., Galizia, F. G., \& Mora, C. (2018). Reconfigurable manufacturing systems : Literature review and research trend. Journal of Manufacturing Systems, 49(July 2017), 93-106. https://doi.org/10.1016/j.jmsy.2018.09.005

Büyüközkan, G., \& Göçer, F. (2017). Application of a new combined intuitionistic fuzzy MCDM approach based on axiomatic design methodology for the supplier selection problem. Applied Soft Computing Journal, 52, 1222-1238. https://doi.org/10.1016/j.asoc.2016.08.051

Chang, D. Y. (1996). Applications of the extent analysis method on fuzzy AHP. European Journal of 
Operational Research, 95(3), 649-655. https://doi.org/10.1016/0377-2217(95)00300-2

Chaube, A., Benyoucef, L., \& Tiwari, M. K. (2012). An adapted NSGA-2 algorithm based dynamic process plan generation for a reconfigurable manufacturing system. Journal of Intelligent Manufacturing, 23(4), 1141-1155. https://doi.org/10.1007/s10845-010-0453-9

Chen, K. S., \& Huang, M. L. (2006). Performance measurement for a manufacturing system based on quality, cost and time. International Journal of Production Research, 44(11), 101-123. https://doi.org/10.1080/00207540500446360

Choi, Y. C., \& Xirouchakis, P. (2015). A holistic production planning approach in a reconfigurable manufacturing system with energy consumption and environmental effects. International Journal of Computer Integrated Manufacturing, 28(4), 379-394. https://doi.org/10.1080/0951192X.2014.902106

Dağdeviren, M. (2010). A hybrid multi-criteria decision-making model for personnel selection in manufacturing systems. Journal of Intelligent Manufacturing, 21(4), 451-460. https://doi.org/10.1007/s10845-008-0200-7

David S. Cochran, Jorge F. Arinez, James W. Duda, and J. L. (2001). A Decomposition Approach for Manufacturing System Design. Journal of Manufacturing Systems, 2, 2013-2015.

Deif, A. M., \& ElMaraghy, W. H. (2006). A Systematic Design Approach for Reconfigurable Manufacturing Systems. Advances in Design, (Dml), 219-228. https://doi.org/10.1007/1-84628-210$1 \_18$

Dixit, A. R., \& Gupta, M. (2013). Current status, enablers \& barriers of implementing cellular manufacturing system in Indian industries. Advances in Manufacturing, 1(4), 346-356. https://doi.org/10.1007/s40436-013-0048-8

Eguia, I., Molina, J. C., Lozano, S., \& Racero, J. (2017). Cell design and multi-period machine loading in cellular reconfigurable manufacturing systems with alternative routing. International Journal of Production Research, 55(10), 2775-2790. https://doi.org/10.1080/00207543.2016.1193673

El Maraghy, H. A. (2006). Flexible and reconfigurable manufacturing systems paradigms. Flexible Services and Manufacturing Journal, 17(4 SPECIAL ISSUE), 261-276. https://doi.org/10.1007/s10696-0069028-7

Garbie, I. (2014). Performance analysis and measurement of reconfigurable manufacturing systems. Journal of Manufacturing Technology Management, 25(7), 934-957. https://doi.org/10.1108/JMTM07-2011-0070

Goyal, K. K., \& Jain, P. K. (2016). Design of reconfigurable flow lines using MOPSO and maximum deviation theory. International Journal of Advanced Manufacturing Technology, 84(5-8), 1587-1600. https://doi.org/10.1007/s00170-015-7760-4

Goyal, K. K., Jain, P. K., \& Jain, M. (2013a). A comprehensive approach to operation sequence similarity based part family formation in the reconfigurable manufacturing system. International Journal of Production Research, 51(6), 1762-1776. https://doi.org/10.1080/00207543.2012.701771

Goyal, K. K., Jain, P. K., \& Jain, M. (2013b). A novel methodology to measure the responsiveness of RMTs in reconfigurable manufacturing system. Journal of Manufacturing Systems, 32(4), 724-730. https://doi.org/10.1016/j.jmsy.2013.05.002

Gumasta, K., Kumar Gupta, S., Benyoucef, L., \& Tiwari, M. K. (2011). Developing a reconfigurability index using multi-attribute utility theory. International Journal of Production Research, 49(6), 16691683. https://doi.org/10.1080/00207540903555536

Haddou Benderbal, H., \& Benyoucef, L. (2019). Machine layout design problem under product family evolution in reconfigurable manufacturing environment: a two-phase-based AMOSA approach. International Journal of Advanced Manufacturing Technology, 104, 375-389. https://doi.org/10.1007/s00170-019-03865-1 
Haddou Benderbal, H., Dahane, M., \& Benyoucef, L. (2018). Modularity assessment in reconfigurable manufacturing system (RMS) design: an Archived Multi-Objective Simulated Annealing-based approach. International Journal of Advanced Manufacturing Technology, 94(1-4), 729-749. https://doi.org/10.1007/s00170-017-0803-2

Heilala, J., \& Voho, P. (2001). Modular reconfigurable flexible final assembly systems. Assembly Automation, 21(1), 20-28. https://doi.org/10.1108/01445150110381646

Hwang, G. (2014). Operational Performance Metrics in Manufacturing Process: Based on SCOR Model and RFID Technology. International Journal of Innovation, Management and Technology, 5(1). https://doi.org/10.7763/ijimt.2014.v5.485

Ighravwe, D. E., \& Oke, S. A. (2017). Ranking maintenance strategies for sustainable maintenance plan in manufacturing systems using fuzzy axiomatic design principle and fuzzy-TOPSIS. Journal of Manufacturing Technology Management, 28(7), 961-992. https://doi.org/10.1108/JMTM-01-20170007

Karim, R., \& Karmaker, C. L. (2016). Machine Selection by AHP and TOPSIS Methods. American Journal of Industrial Engineering, Vol. 4, 2016, Pages 7-13, 4(1), 7-13. https://doi.org/10.12691/AJIE-4-1-2

Koren, Y., Gu, X., \& Guo, W. (2017). Recon fi gurable manufacturing systems : Principles , design , and future trends. Front. Mech. Eng., 13(2), 121-136. https://doi.org/https://doi.org/10.1007/s11465-0180483-0

Koren Y., Heisel, U., Jovane, F., Moriwaki, T., Pritschow, G., Ulsoy, G., \& Van Brussel, H. (1999). Reconfigurable manufacturing systems. CIRP Annals - Manufacturing Technology, 48(2), 527-540. https://doi.org/10.1016/S0007-8506(07)63232-6

Koren, Y., \& Shpitalni, M. (2010). Design of reconfigurable manufacturing systems. Journal of Manufacturing Systems, 29(4), 130-141. https://doi.org/10.1016/j.jmsy.2011.01.001

Kumar, J. (2013). Maintenance Performance Metrics for Manufacturing Industry. International Journal of $\begin{array}{lllll}\text { Research in } & \text { Engineering } 136 .\end{array}$ https://doi.org/10.15623/ijret.2013.0202009

Kurttila, M., Pesonen, M., Kangas, J., \& Kajanus, M. (2000). Utilizing the analytic hierarchy process $\check{Z}$ AHP . in SWOT analysis $\square$ a hybrid method and its application to a. Forest Policy and Economics 1, 41-52.

Lozano, S., Villa, G., \& Eguía, I. (2017). Data envelopment analysis with multiple modes of functioning. Application to reconfigurable manufacturing systems. International Journal of Production Research, 55(24), 7566-7583. https://doi.org/10.1080/00207543.2017.1391418

Maganha, I., Silva, C., \& Ferreira, L. M. D. F. (2018). Understanding reconfigurability of manufacturing systems: An empirical analysis. Journal of Manufacturing Systems, 48(July), 120-130. https://doi.org/10.1016/j.jmsy.2018.07.004

Mapes, J. (2000). Process variability and its effect on plant performance. International Journal of $\begin{array}{llll}\text { Operations } \quad \text { and } & \text { Production }\end{array}$ https://doi.org/10.1108/01443570010330775

Mehrabi, M. G., Ulsoy, A. G., \& Koren, Y. (2000). Reconfigurable manufacturing systems: key to future manufacturing. Journal of Intelligent Manufacturing, 11(4), $403-419$. https://doi.org/10.1023/A:1008930403506

Mittal, K. K., \& Jain, P. K. (2014). An overview of performance measures in reconfigurable manufacturing system. Procedia Engineering, 69, 1125-1129. https://doi.org/10.1016/j.proeng.2014.03.100

Mubarok, K., \& Faculty, E. (2010). The issues for the implementation of reconfigurable manufacturing systems in small and medium. ARIKA, Pebruari 2010, 04(1), ISSN: 1978-1105.

Prasad, D., \& Jayswal, S. C. (2019a). A Review on Flexibility and Reconfigurability in Manufacturing 
System. In Innovation in Materials Science and Engineering. https://doi.org/10.1007/978-981-132944-9

Prasad, D., \& Jayswal, S. C. (2019b). Assessment of a reconfigurable manufacturing system. Benchmarking. https://doi.org/10.1108/BIJ-06-2018-0147

Prashar, A. (2016). A conceptual hybrid framework for industrial process improvement: integrating Taguchi methods, Shainin System and Six Sigma. Production Planning and Control, 27(16), 13891404. https://doi.org/10.1080/09537287.2016.1225999

Rao, R. V., \& Patel, B. K. (2010). Decision making in the manufacturing environment using an improved PROMETHEE method. International Journal of Production Research, 48(16), 4665-4682. https://doi.org/10.1080/00207540903049415

Saaty, T. L. (2008). Decision making with the analytic hierarchy process. Int. J. Services Sciences, 1(1), 83-98.

Sânchez, A. M., \& Pérez, M. P. (2001). Lean indicators and manufacturing strategies. International Journal of Operations and Production Management, 21(11), 1433-1451. https://doi.org/10.1108/01443570110407436

Sindhwani, R., \& Malhotra, V. (2018). An integrated approach for implementation of agile manufacturing system in an Indian manufacturing industry. Benchmarking, 25(4), 1106-1120. https://doi.org/10.1108/BIJ-01-2017-0017

Singh, R. K., Khilwani, N., \& Tiwari, M. K. (2007). Justification for the selection of a reconfigurable manufacturing system: a fuzzy analytical hierarchy based approach. International Journal of Production Research, Vol. 45, N(February 2014), 37-41. https://doi.org/10.1080/00207540600844043

Spicer, P., \& Carlo, H. J. (2007). Integrating reconfiguration cost into the design of multi-period scalable reconfigurable manufacturing systems. Journal of Manufacturing Science and Engineering, Transactions of the ASME, 129(1), 202-210. https://doi.org/10.1115/1.2383196

Touzout, F. A., \& Benyoucef, L. (2019). Multi-objective sustainable process plan generation in a reconfigurable manufacturing environment : exact and adapted evolutionary approaches. International Journal of Production Research, O(0), 1-17. https://doi.org/10.1080/00207543.2018.1522006

Wiendahl, H. P., ElMaraghy, H. A., Nyhuis, P., Zäh, M. F., Wiendahl, H. H., Duffie, N., \& Brieke, M. (2007). Changeable Manufacturing - Classification, Design and Operation. CIRP Annals Manufacturing Technology, 56(2), 783-809. https://doi.org/10.1016/j.cirp.2007.10.003

Wiendahl, H. P., \& Heger, C. L. (2011). Justifying Changeability. A Methodical Approach to Achieving Cost Effectiveness. Journal for Manufacturing Science and Production, 6(1-2), 33-40. https://doi.org/10.1515/ijmsp.2004.6.1-2.33

Yadav, G., Seth, D., \& Desai, T. N. (2018). Application of hybrid framework to facilitate lean six sigma implementation: a manufacturing company case experience. Production Planning and Control, 29(3), 185-201. https://doi.org/10.1080/09537287.2017.1402134

Yi, G., Wang, Y., \& Zhao, X. (2018). Evaluation and optimization of the design schemes of reconfigurable machine tools based on multiple-attribute decision-making. Advances in Mechanical Engineering, 10(12), 1-9. https://doi.org/10.1177/1687814018813054

Yurdakul, M. (2002). Measuring a manufacturing system's performance using Saaty's system with feedback approach. Integrated Manufacturing $\quad$ Systems, $13(1), \quad 25-34$. https://doi.org/10.1108/09576060210411486 
Figures

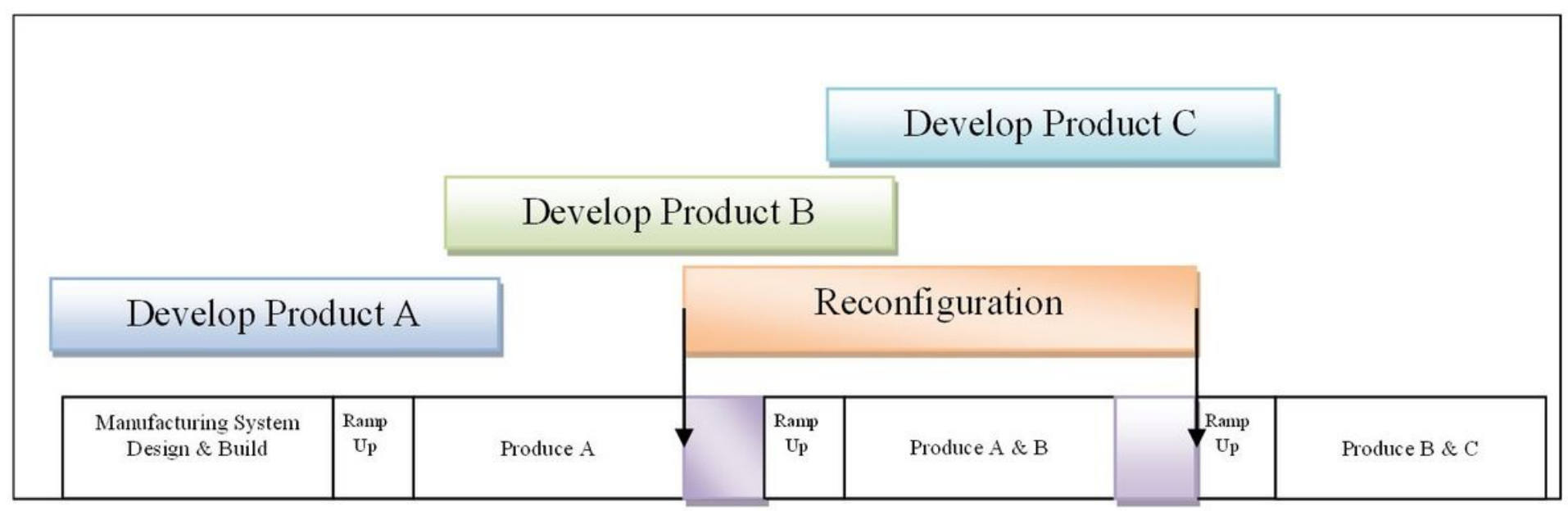

Figure 1

Adaptation to production of new products through rapid reconfiguration (Koren Y. et al., 1999) 


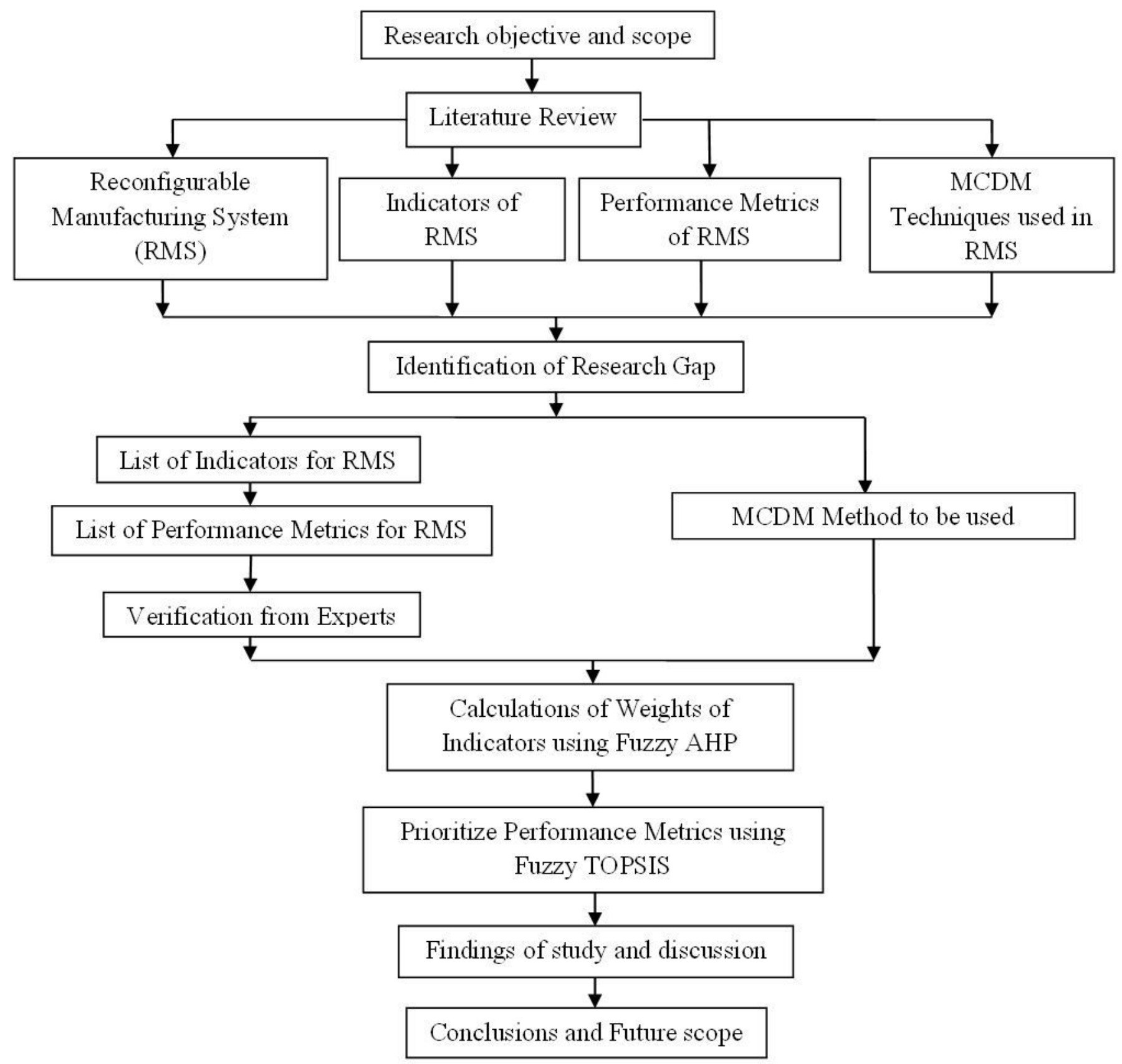

Figure 2

Flow chart for Research methodology 


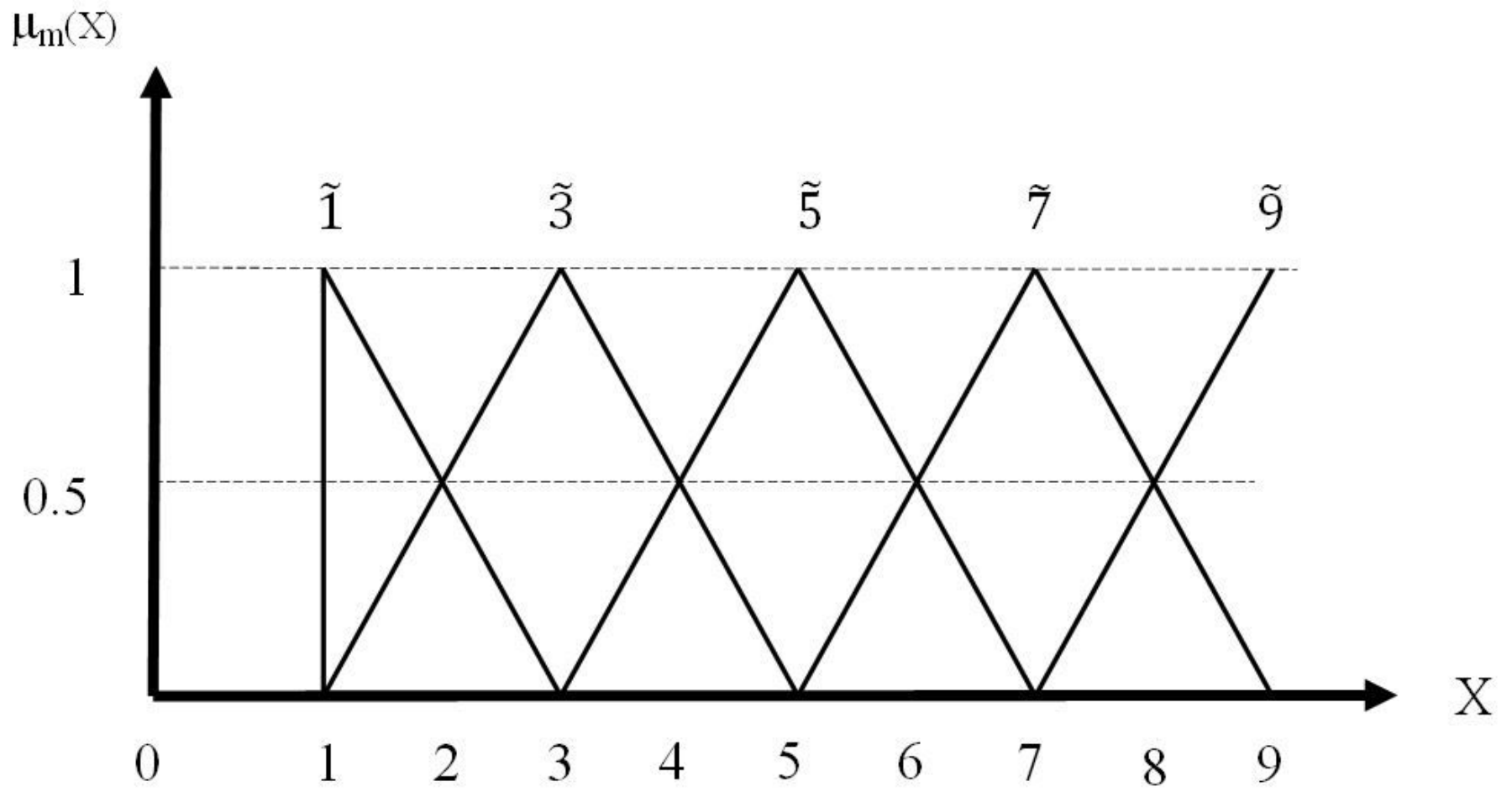

Figure 3

\section{Triangular Fuzzy numbers}

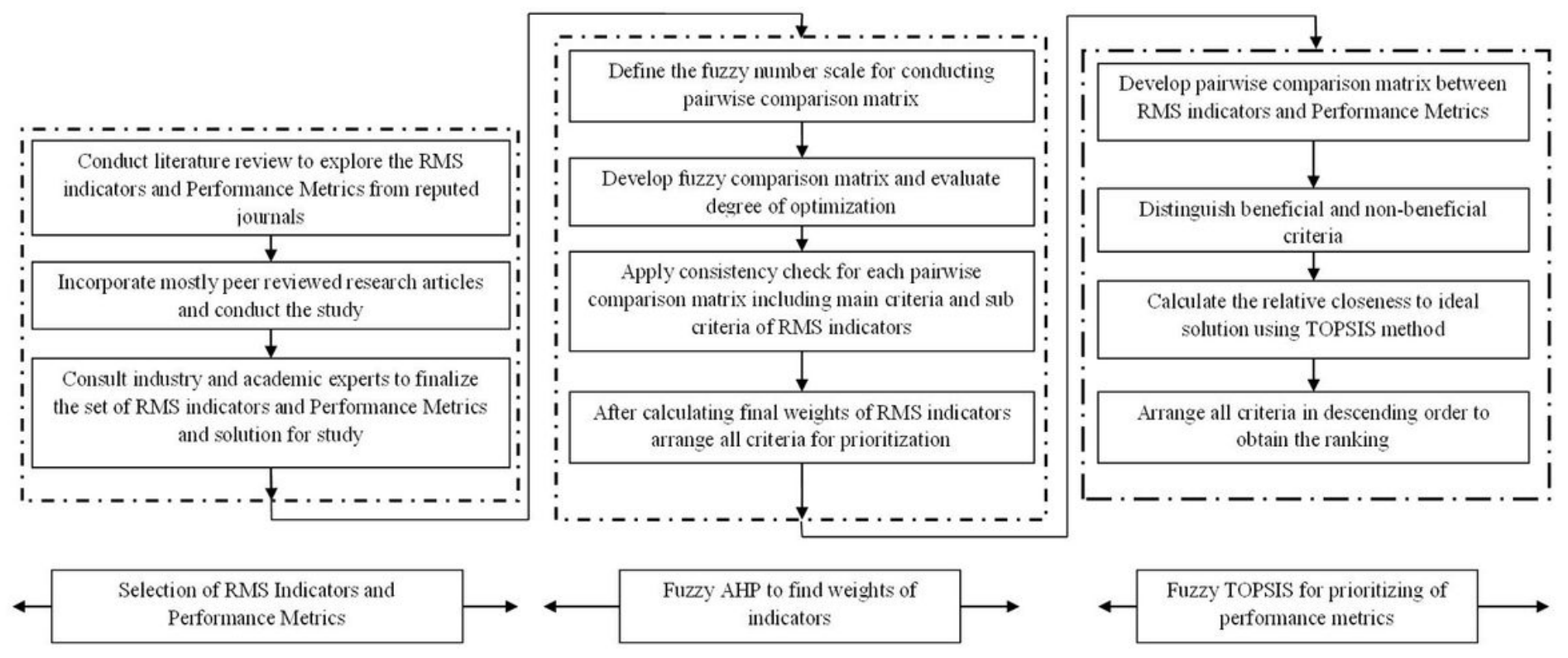

Figure 4

A proposed three-stage hybrid framework 


\section{Prioritize the Performance Metrics of RMS}

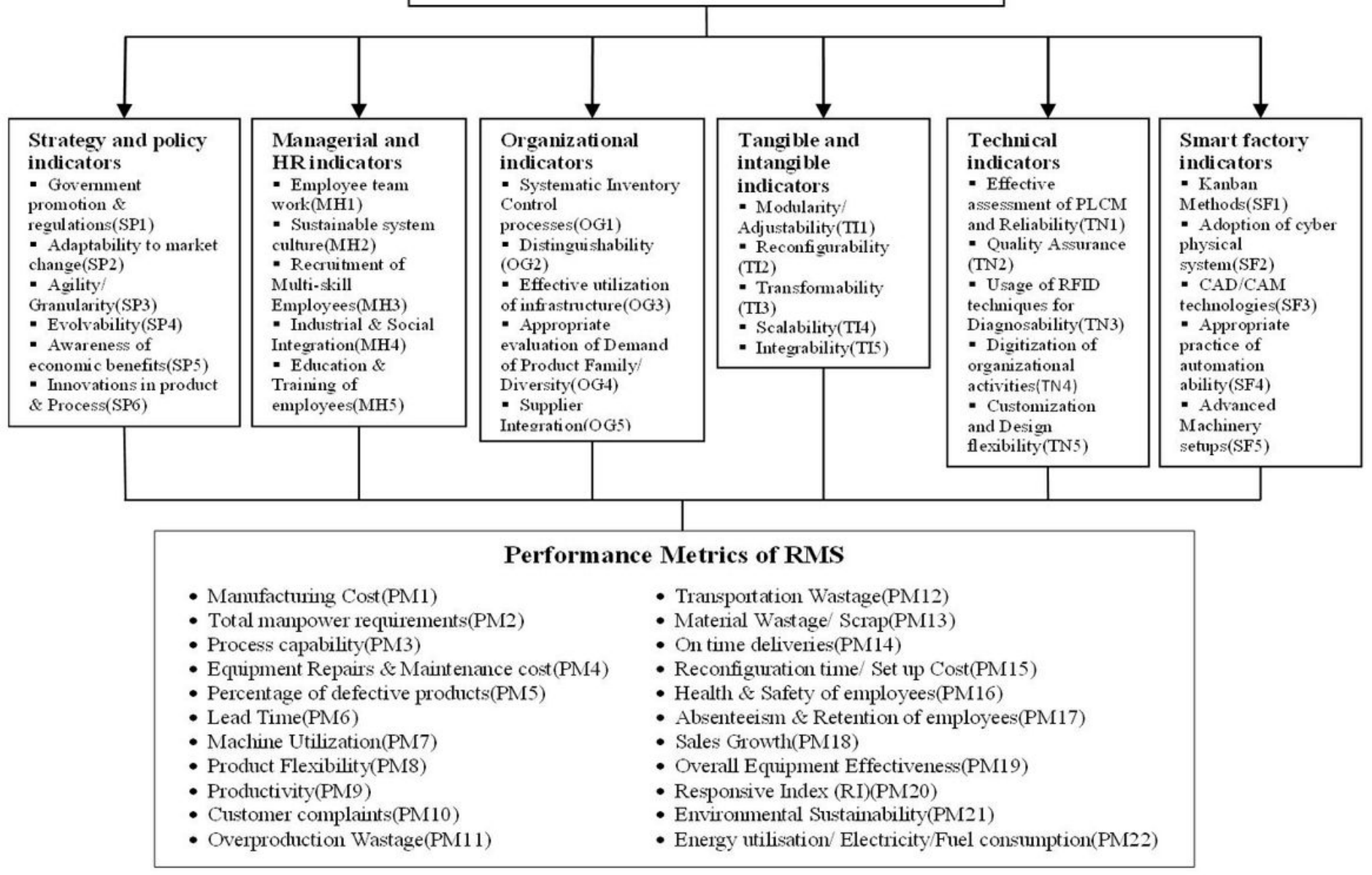

Figure 5

Hierarchical structure of Indicators 